\title{
Phony peach disease: past and present impact on the peach industry in the southeastern U.S.A
}

\author{
Kendall A. Johnson ${ }^{1}$, Clive H. Bock ${ }^{2}$ and Phillip M. Brannen ${ }^{1 *}$ (1)
}

\begin{abstract}
Background: Phony peach disease (PPD) is caused by the plant pathogenic bacterium Xylella fastidiosa subsp. multiplex (Xfm). Historically, the disease has caused severe yield loss in Georgia and elsewhere in the southeastern United States, with millions of PPD trees being removed from peach orchards over the last century. The disease remains a production constraint, and management options are few. Limited research has been conducted on PPD since the 1980s, but the advent of new technologies offers the opportunity for new, foundational research to form a basis for informed management of PPD in the U.S. Furthermore, considering the global threat of Xylella to many plant species, preventing import of Xfm to other regions, particularly where peach is grown, should be considered an important phytosanitary endeavor.

Main topics: We review PPD, its history and impact on peach production, and the eradication efforts that were conducted for 42 years. Additionally, we review the current knowledge of the pathogen, Xfm, and how that knowledge relates to our understanding of the peach-Xylella pathosystem, including the epidemiology of the disease and consideration of the vectors. Methods used to detect the pathogen in peach are discussed, and ramifications of detection in relation to management and control of PPD are considered. Control options for PPD are limited. Our current knowledge of the pathogen diversity and disease epidemiology are described, and based on this, some potential areas for future research are also considered.

Conclusion: There is a lack of recent foundational research on PPD and the associated strain of Xfm. More research is needed to reduce the impact of this pathogen on peach production in the southeastern U.S., and, should it spread internationally, wherever peaches are grown.
\end{abstract}

Keywords: Stone fruit, Peach, Xylella fastidiosa, Disease management, Yield loss, Fruit weight

\section{Background}

Peach Prunus persica (L.) Batsch, is a woody perennial that grows to a height of approximately 4.5 to $7.6 \mathrm{~m}$. Peach is native to China, and peach pits have been found at Neolithic sites in China dating back to 7000 BCE, where peach domestication began at least 4000 years ago

*Correspondence: pbrannen@uga.edu

${ }^{1}$ Department of Plant Pathology, University of Georgia, 2105 Miller Plant Sciences Building, Athens, GA 30602, USA

Full list of author information is available at the end of the article
(Huang et al. 2008; Okie 2016). Peaches were mentioned in Chinese literature predating $1000 \mathrm{BCE}$ (Huang et al. 2008), were transported along trading routes from China to the Middle East (the Silk Road) (Gould 1918; Savage 1983; Okie 2016), and are thought to have arrived in Europe in the $1^{\text {st }}$ or second century BCE; they are mentioned by Virgil (71-19 BCE) and Pliny the Elder (79-23 BCE). Spread continued throughout the Mediterranean region and into areas of modern-day France and Spain (Okie 2016). original author(s) and the source, provide a link to the Creative Commons licence, and indicate if changes were made. The images or other third party material in this article are included in the article's Creative Commons licence, unless indicated otherwise in a credit line to the material. If material is not included in the article's Creative Commons licence and your intended use is not permitted by statutory regulation or exceeds the permitted use, you will need to obtain permission directly from the copyright holder. To view a copy of this licence, visit http://creativecommons.org/licenses/by/4.0/. The Creative Commons Public Domain Dedication waiver (http://creativeco mmons.org/publicdomain/zero/1.0/) applies to the data made available in this article, unless otherwise stated in a credit line to the data. 
Spanish colonist and Jesuit friars spread peach to the new world, and peach was established in 1565 at St. Augustine, Florida and in 1571 on St. Simons and Cumberland Islands, Georgia (Scherm et al. 2004; Okie 2016). Native American tribes who encountered the Spanish adopted the peach as part of their diet, and the crop was spread inland via trade routes throughout the eastern seaboard of the United States (U.S.). In the U.S., commercial peach production was limited until the latter part of the nineteenth century. Key factors critical to the development of peach as a commercial success in the southeastern U.S. included (1) the abolition of slavery and the need for an alternative commodity to replace cotton; (2) an increased interest in horticulture, particularly the development of peach varieties and nurseries in Georgia; (3) development of 'Elberta', a premiere peach for packing and shipping, by Samuel H. Rumph at Marshallville, Georgia in 1870; and (4) the advent of the railroads and refrigerated rail cars (Scherm et al. 2004; Okie 2016).

Peach production in Georgia peaked in the 1920s (Fig. 1), but due to a litany of challenges, production declined quite dramatically after 1925 , and is now only $10 \%$ of the peak production. Despite the precipitous decline, Georgia remains the third largest producer of fresh peaches in the U.S., after California and South Carolina. Nationally, peach is still an economically important fruit crop in the U.S. In 2019, there were 30,109 ha of bearing peach cultivated in ten states, valued at an estimated U.S. \$519 million in utilized peach fruit production (USDA National Agricultural Statistics Service 2020). However, there are numerous diseases that impact peach production in the U.S., and these are described in the American Phytopathological Society's "The Compendium of Stone Fruit Diseases" (Ogawa et al. 1995). Phony peach disease (PPD), the subject of this review, is caused by the fastidious plant pathogenic bacterium Xylella fastidiosa subsp. multiplex Schaad, Postnikova, Lacy, Fatmic \& Chang (Xf, Xfm). Prior to and during the early years following the advent of management recommendations, losses to PPD were significant on an annual basis (Table 1), with many middle to southern Georgia farms suffering greater than $50 \%$ losses; in 1930, researchers speculated that PPD would wipe out peach production in Georgia if left unchecked (Alden 1930). Even today, where peaches are grown in Georgia, losses are still significant on an annual basis (Brannen 2018). It is worth noting that Xylella-related diseases cause severe damage to many crops around the world and thus, the pathogen has attracted much attention as new insights are desperately needed for management of these diseases (Sicard et al. 2018). Most recently, hundreds of thousands of olive trees (and likely other species) in southern Italy and other European countries are under serious threat from Xylella that causes Olive Quick Decline Syndrome (OQDS), and which is transmitted by spittlebugs, Philaenus spumarius, a common vector of

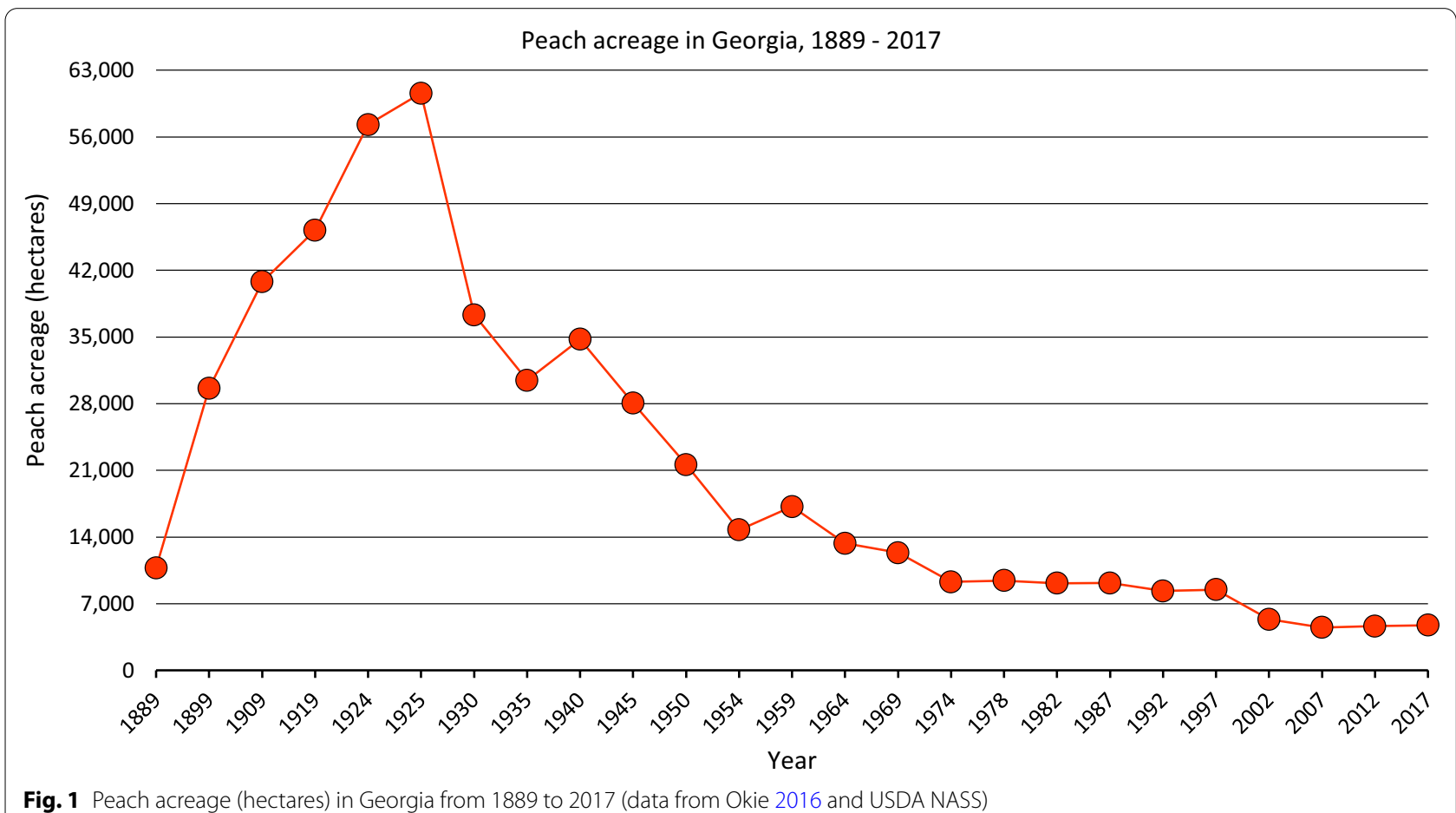

Fig. 1 Peach acreage (hectares) in Georgia from 1889 to 2017 (data from Okie 2016 and USDA NASS) 
Table 1 Losses of peach trees to phony peach disease in Georgia (U.S.) in the initial four years of the USDA survey and roguing programs (1929-1932)

\begin{tabular}{llcl}
\hline Year & Trees inspected & Infected trees & $\begin{array}{l}\text { Percent } \\
\text { rogued }\end{array}$ \\
\hline $1929^{\mathrm{a}}$ & $9,161,373$ & 79,847 & 0.9 \\
$1930^{\mathrm{a}}$ & $9,779,035$ & 213,376 & 2.2 \\
$1931^{\mathrm{b}}$ & $9,643,844$ & 97,758 & 1.0 \\
$1932^{\mathrm{b}}$ & $3,032,733$ & 35,112 & 1.2
\end{tabular}

${ }^{a}$ Georgia State Board of Entomology. Biennial Report of the State Entomologist for 1929-1930. Bulletin 75. May (1931). Phony Peach Diseases and Summary of Inspection for Phony Peach Disease, U.S. Department of Agriculture and Georgia State Board of Entomology Cooperating

${ }^{b}$ Georgia State Board of Entomology. Biennial Report for the State Entomologist for 1931-1932. Bulletin 77. June (1933). Special Regulatory Projects: Phony Peach Disease, U.S. Department of Agriculture and Georgia State Board of Entomology Cooperating

Xylella species for some hosts (Cornara et al. 2017). In this review we describe PPD, the history of the disease and its management, the subsp. of Xf that causes PPD, and provide an update on what is known of the epidemiology, biology and control of the pathogen. We will use this information as a basis to define research priorities to improve our understanding and knowledge of PPD, the causal organism, and management of the disease.

\section{Phony peach disease}

Historically, PPD is one of the most important diseases of peach in the southeastern U.S. and especially in Georgia. PPD was first observed by Samuel Rumph in 1885 in two peach trees near Marshallville, Georgia (Hutchins et al. 1951; Anderson 1956; Cochran and Hutchins 1976); however, it was not until a few decades later that PPD impacted peach production across the state (Hutchins 1933; Alden 1939; Hutchins et al. 1951). Rumph noted the trees were dwarfed and referred to them as "pony trees," but later the disease was called phony peach (Neal 1920). It was speculated that this name came from the infected trees appearing healthy with dark green and abundant foliage and yet producing limited fruit of poor quality and size (Fig. 2), rendering them useless (Savage 1983). Reported outbreaks of PPD, mainly in Georgia, were significant in 1929, 1951, and 1976 (Hutchins 1933; Cochran and Hutchins 1976; Janse and Obradovic 2010). Although PPD is typically found in the southeastern U.S., it has since been reported as far west as New Mexico and in northern states including Missouri and Illinois (Hopkins et al. 1973; Hopkins 1989; Randall et al. 2011). Isolated cases were also reported in Indiana, Kentucky, Maryland and Pennsylvania (Cochran and Hutchins 1976). All varieties, races and hybrids of peach are susceptible to PPD (Cochran and Hutchins 1976).

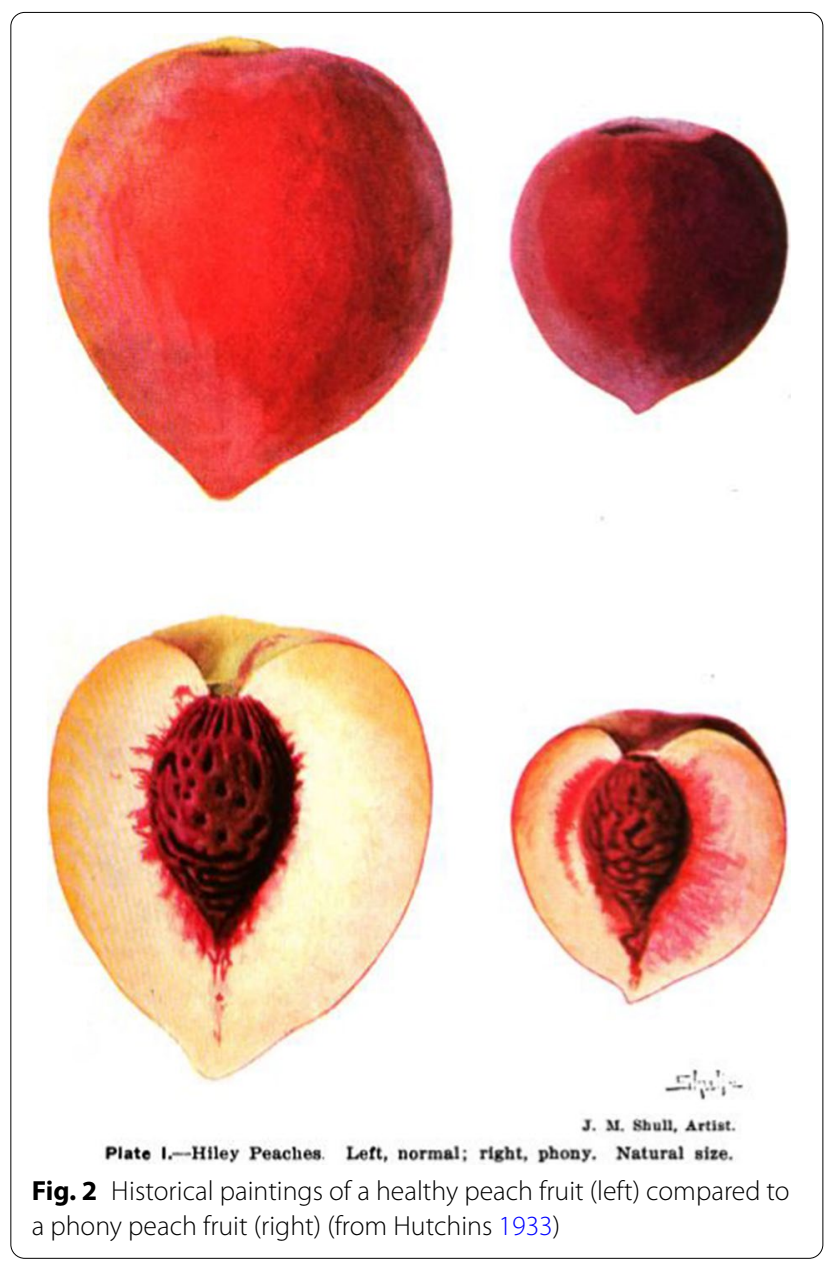

\section{Symptoms of PPD}

Most species that develop disease due to infection with $\mathrm{Xf}$ exhibit symptoms consistent with blocking of the xylem, including wilting and marginal necrosis (manifesting as scorch symptoms) of the leaves (Purcell 1987). However, Xf-infected peach trees do not display these typical symptoms. PPD is characterized by progressive symptoms that include a denser/flattened tree canopy (Fig. 3A), shortened internodes (Figs. 3B and C), flattened darker-green leaves, abnormal growth, early bloom and leaf emergence (Fig. 4), delayed leaf senescence, and reduced fruit size and quality (Fig. 2) (Neal 1920; Hutchins 1933; Smith 1941; Cavanagh and Rothe 1953; USDA-ARS 1962; Fogle et al. 1974; Cochran and Hutchins 1976; Mizell et al. 2008). Although diseased trees can be identified by early summer, symptoms are more evident later in the summer (July and August) as healthy tree shoot growth exceeds that of PPD trees (Fogle et al. 1974); however, trees can be inspected for symptoms from June to October depending on location (Cavanagh and Rothe 1953). As infected trees age, dieback of shoots 


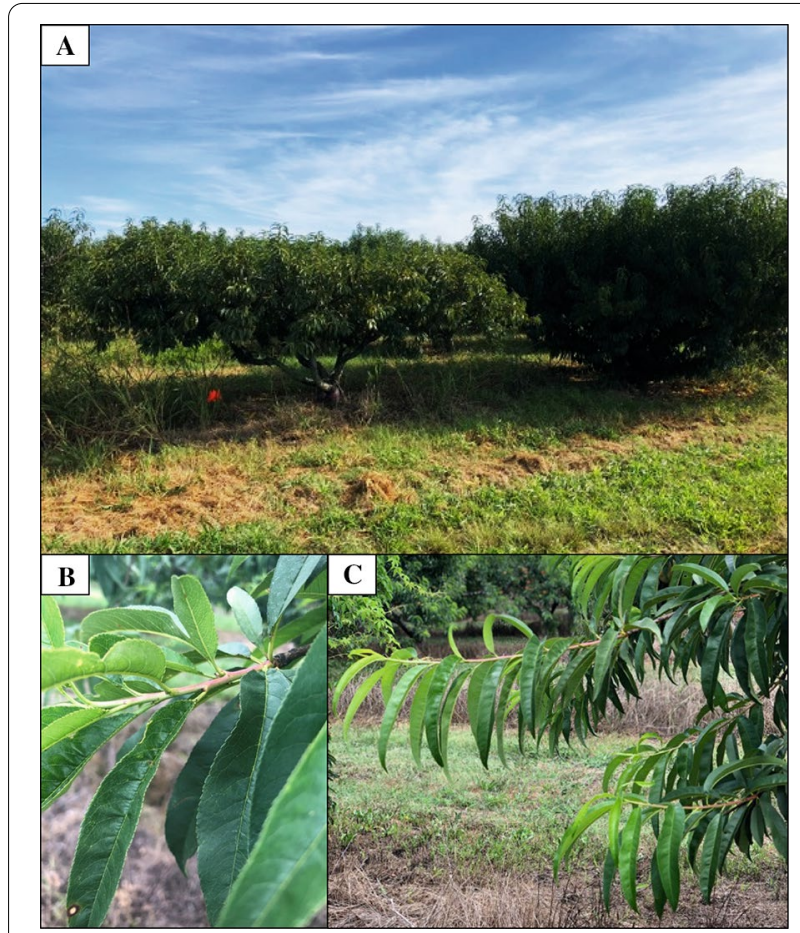

Fig. 3 Foliar symptoms of phony peach disease (PPD): $\mathbf{A}$ tree showing PPD symptoms (left) compared to a healthy tree with normal growth (right). Xylella fastidiosa subsp. multiplex infected trees have shortened internodes, flattened tops and often darker green foliage; $\mathbf{B}$ shortened internodes on a phony peach diseased tree; and $\mathbf{C}$ normal spacing between internodes on a healthy peach tree

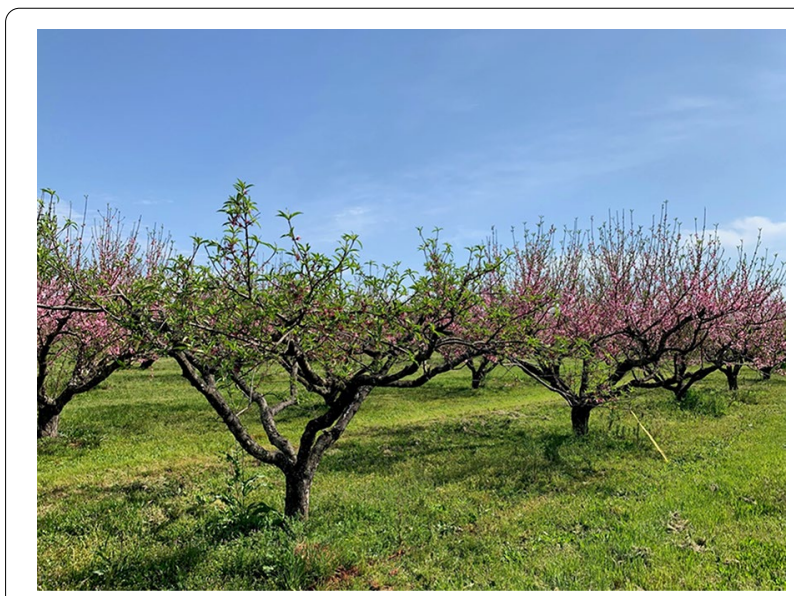

Fig. 4 Tree with phony peach disease (foreground) showing advanced petal fall (bloom) and leaf development as compared to healthy trees in the background (still in full bloom and with limited leaf expansion)

can be observed (Fig. 5) (Hutchins 1933; Smith 1941; Cochran and Hutchins 1976). After infection, symptoms of PPD typically take approximately 18 months to

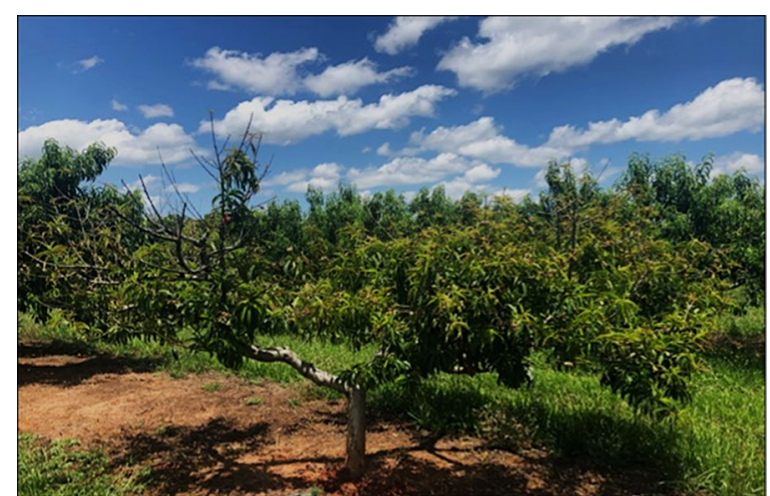

Fig. 5 Dieback symptoms on shoots of a peach tree with advanced phony peach disease caused by Xylella fastidiosa subsp. multiplex

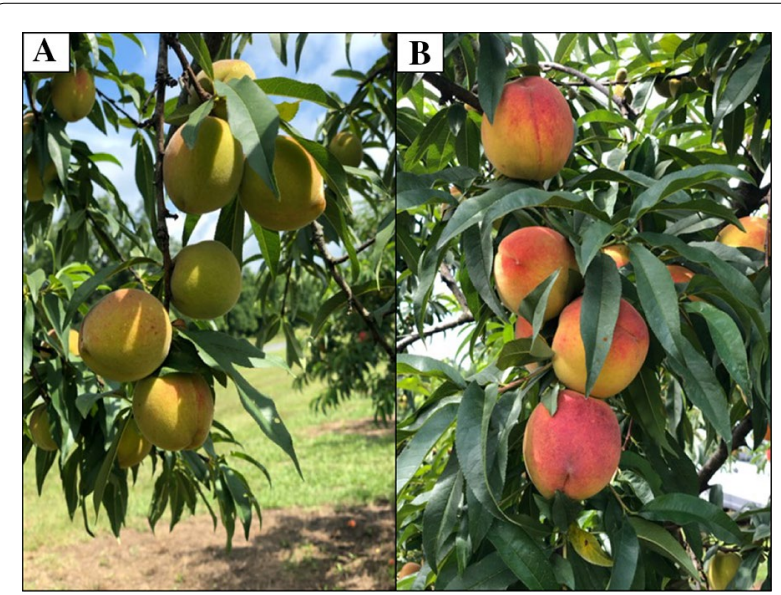

Fig. 6 Peach fruit ripeness (color) comparisons on June 23, 2020. Fruit on a tree with phony peach disease $\mathbf{A}$ are less mature and ripe as compared to $\mathbf{B}$ fruit on a healthy peach tree

appear, although estimates range from one to three years (Cavanagh and Rothe 1953; Davis et al. 1981); to further complicate visual diagnostics, symptoms may not develop uniformly throughout the tree (Davis et al. 1981), possibly due to uneven distribution of bacteria. Indeed, bacteria are not uniformly distributed in the canopies of naturally diseased peach trees (Cochran and Hutchins 1976). Generally three to five years from the appearance of symptoms, fruit size and quantity are reduced, although fruit color may be enhanced (Cochran and Hutchins 1976); however, any fruit that are produced are of poor flavor, rendering them unmarketable (Neal 1920; Hutchins 1933; Smith 1941; Hopkins 1989). Ripening date among varieties varies, but trees infected with PPD have been reported to mature an estimated ten to twelve days later than typical for that variety (Fig. 6) (Neal 1920). A longer ripening time is also associated with poor taste, and this may further explain the negative sensory 
characteristics of fruit from PPD trees. However, Hutchins et al. (1951) reported that fruit from PPD trees mature earlier than normal trees, so the fruit maturation characteristic is not clearly of diagnostic value, and should be revisited. A further characteristic that has been observed is bronzing of leaves later in the season during September and October (P. Brannen, personal observation). Various reports have indicated that PPD will not kill a peach tree, but as the disease progresses, large limbs die or senesce prematurely contributing to the appearance of tree death (Cochran and Hutchins 1976; Mizell et al. 2008). Death of PPD trees may be related to weakened trees and winter injury, or other declines (Fogle et al. 1974). However, there is no evidence that PPD per se does not eventually kill the tree.

\section{Distribution of PPD—past and present}

After PPD was first observed near Marshallville, Georgia in 1885 and prior to initiation of eradication efforts, the disease spread rapidly and resulted in an estimated loss of one million trees in Georgia alone (Hutchins 1933; Alden 1939; Smith 1941). However, PPD was not considered an important peach disease until 1915 when J. H. Hale, a key figure in the U.S. peach industry (Okie 2016), wrote to the Fruit Disease Investigation, Bureau of Plant Industry seeking help due to the thousands of infected trees in the Fort Valley area (Fig. 7) (Hutchins 1933; Cavanagh and Rothe 1953). By 1920, the disease was prevalent in 16 surrounding counties (Lewis 1921), and it was soon reported in Alabama and Mississippi (Alden 1930; Alden 1939; Hutchins et al. 1951; Anderson 1956). The rise of PPD was likely coincidentally tied to the rise of peach production in Georgia, which likewise peaked in the

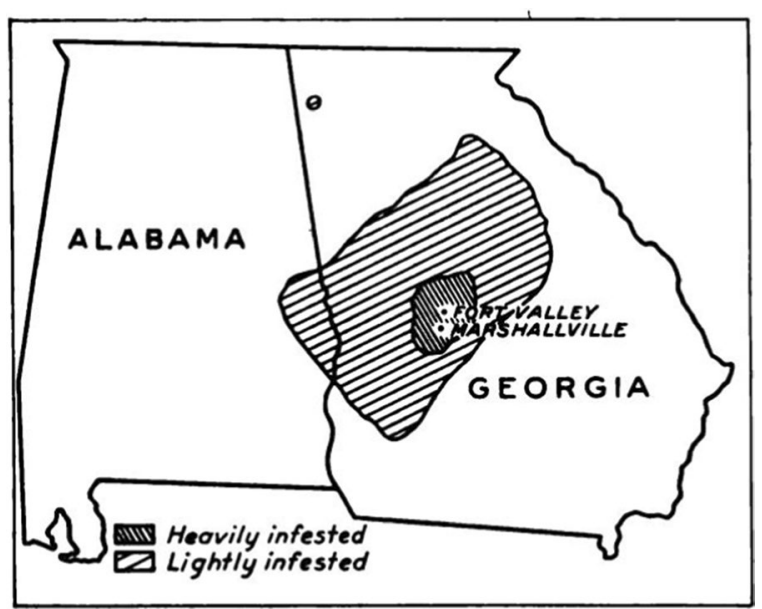

Fig. 7 Distribution of phony peach disease (caused by Xylella fastidiosa subspecies multiplex) in Georgia and Alabama in December 1928 (from Hutchins 1933) 1920s (Fig. 1); although peach production was greater in the central portion of Georgia, as today, all counties had some production and peach was a significant commercial enterprise in many northern counties as well (Fig. 8). The Bureau of Plant Industry, USDA, initiated research on PPD in 1921 (Hutchins et al. 1951). In 1929, state and federal campaigns were implemented to eradicate PPD and to restrict movement of peach and nectarine nursery stock from affected areas (Georgia State Board of Entomology 1931; Hutchins et al. 1951). As survey data from this period shows (Fig. 9), by 1929 and 1930, the disease was particularly severe in middle and southern Georgia counties; the 1929 and 1930 data likely represent the peak of PPD in Georgia, as prior to this the spread was largely unimpeded by any control measures. By 1941 PPD extended west to Texas and north to Illinois (Smith 1941). Indeed, surveys between 1929 and 1952 found PPD in Alabama, southern Arkansas, northern Florida, Georgia, Louisiana, Mississippi, south central South Carolina, and eastern Texas. In addition, limited and isolated areas of disease were reported in southern Illinois, Indiana, Kentucky, southern Missouri, Maryland, North Carolina, southern Oklahoma, Pennsylvania and Tennessee (Figs. 10 and 11) (Cavanagh and Rothe 1953; Cochran and Hutchins 1976). Even with extensive efforts to address PPD, ultimately it caused crop loss in seventeen states (USDA-ARS 1962).

During the early phases of PPD spread, production trees were propagated via budwood grafted to rootstock seedlings, as they are now. Growers were urged to be cautious when selecting budwood in areas with a high incidence of PPD (Neal 1920). Due to their potential as sources of inoculum, the PPD campaign included eradication of all plum trees within $274 \mathrm{~m}$ of peach orchards (Cavanagh and Rothe 1953; KenKnight 1961a); it was also further recommended that plums be removed within the $274 \mathrm{~m}$ zone at least a year prior to planting peach, assuming that vectors would not maintain the causal agent for more than one year; the causal agent was originally thought to be viral (Cavanagh and Rothe 1953). Rotation away from peach for at least one year was recommended before replanting. Although PPD was reported in Illinois, Kentucky, Indiana, Maryland, and Pennsylvania, it did not generally spread beyond the trees that initially presented symptoms (Turner and Pollard 1959a). Indeed, there was decrease in PPD incidence at greater altitudes and latitudes (Figs. 9, 10, 11), possibly due to colder winter conditions, although other factors could apply.

As mentioned, a cooperative program between federal and state agencies was implemented to survey and remove PPD-trees from orchards, resulting in PPD being eliminated from ten states and the disease incidence reduced elsewhere. Cavanagh and Rothe (1953) reported 


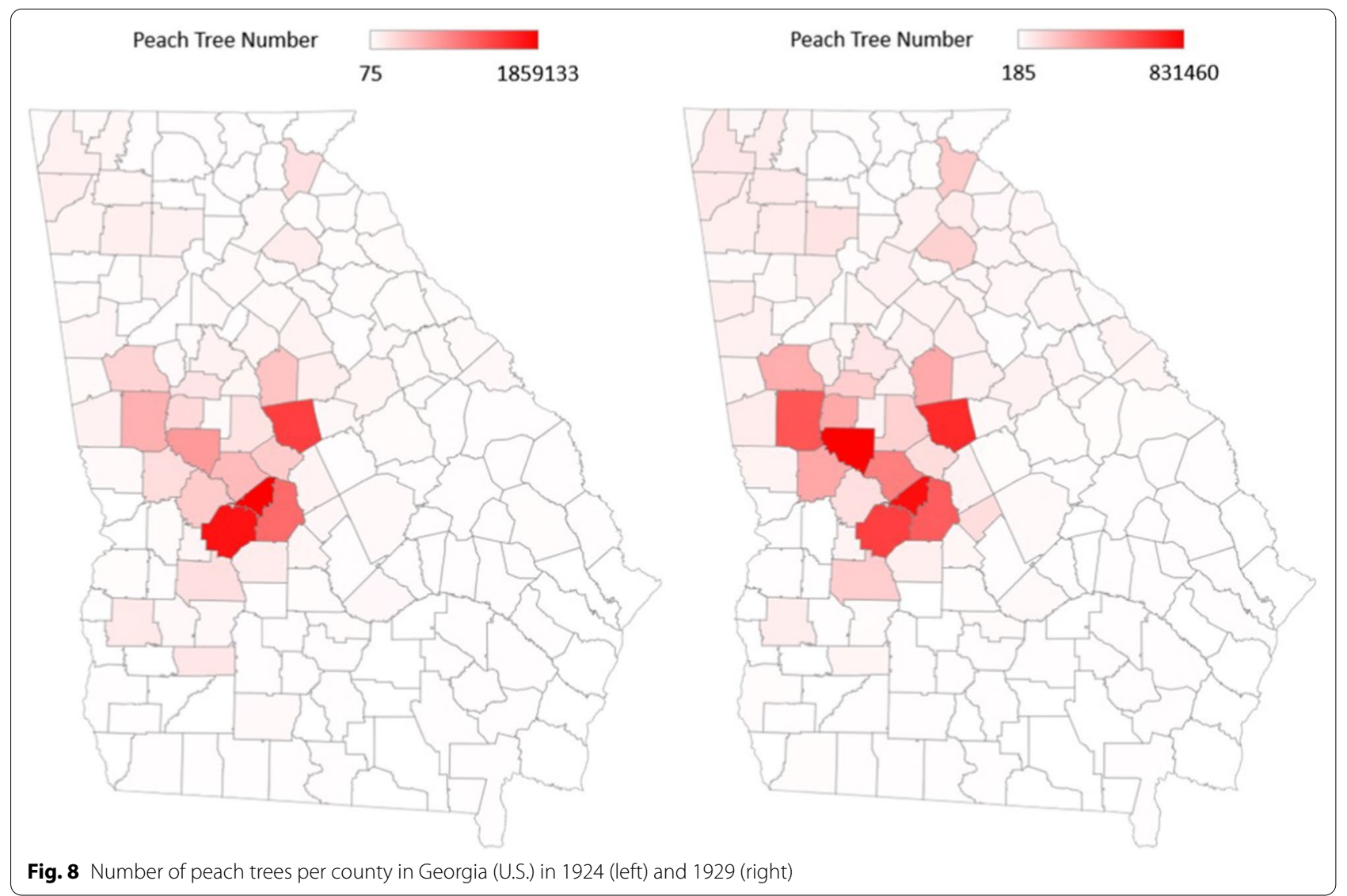

that PPD was eradicated from Illinois, Indiana, Maryland, Oklahoma, and Pennsylvania and from more than 100 counties in other lightly affected states. Reflecting the program's success, during the early 1970s the incidence of PPD in Georgia peach orchards was considered negligible, although outbreaks occurred where orchards did not receive insect management programs (Cochran and Hutchins 1976). But in 1972, federal budget cuts resulted in the PPD eradication programs being discontinued, leaving Florida and Georgia with serious PPD outbreaks (French 1980). In 1974, the USDA reported that PPD remained serious in Georgia and Alabama, even though two million PPD trees had been removed in Georgia alone since 1930 (Cochran and Hutchins 1976; Fogle et al. 1974). Previous reports indicated that one million trees had been critically diseased in Georgia by 1929 (Hutchins et al. 1951; Cavanagh and Rothe 1953), so by 1972, at least 3 million trees total were destroyed due to PPD in Georgia alone. Some areas were simply prone to PPD based on location. Cavanagh and Rothe (1953) concluded the Fort Valley-Marshallville area of Georgia, where PPD was first reported, had taken the heaviest toll from PPD, likely due to: (1) primary vector abundance, (2) peach and plum density, and (3) favorable local ecology for PPD. Prior to eradication efforts, records from this area indicated that it was not uncommon for $50 \%$ of trees to be infected by $6-8$ years after planting, and an incidence as high as $99 \%$ was often observed in 12-year-old orchards (Hutchins et al. 1951).

The various studies described in this section include the most recent data that exist defining the occurrence of PPD in the southeastern U.S. There have been no surveys conducted to determine the prevalence of PPD in peach orchards anywhere in the U.S. since the 1970's (French 1980).

\section{The Pathogen: Xylella fastidiosa}

Though much of the history or Xf and PPD in North America remains shrouded due to the passage of time, the development of PPD has been ultimately tied to the introduction of a susceptible Old World plant, peach, with an aggressive New World pathogen, Xf. Thus, our knowledge of $\mathrm{Xf}$ as a pathogen of peach and the resulting disease, PPD, has evolved over time (Fig. 12). Xf is a xylem-limited bacterium classified in the family Xanthomonadaceae (Rapicavoli et al. 2018). The bacterium colonizes a wide range of host plants that includes more than 350 species, but reports where there is a pathogenic 

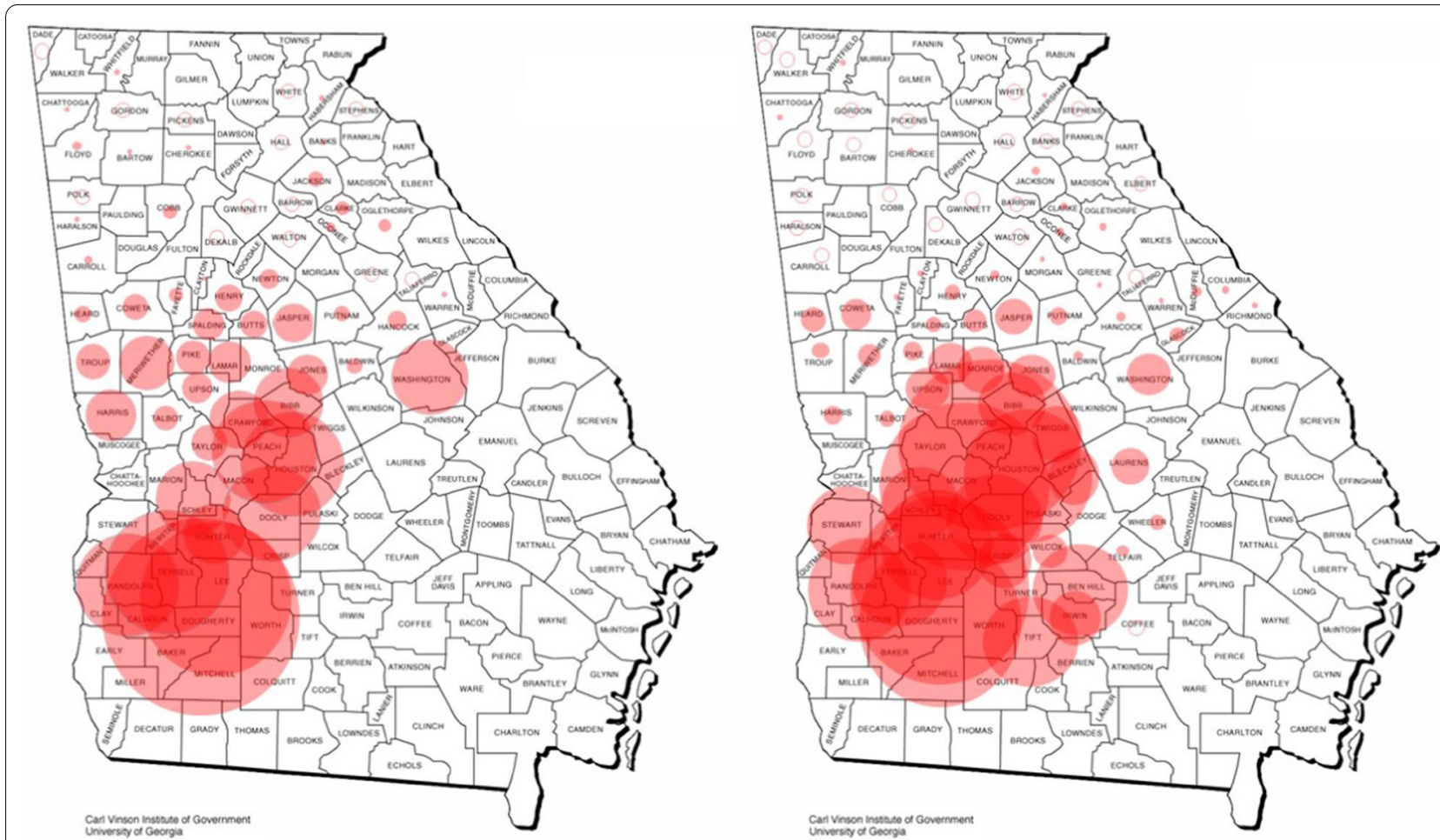

Fig. 9 Distribution of phony peach disease (PPD, caused by Xylella fastidiosa subspecies multiplex) by surveyed county in Georgia (U.S.) in 1929 (left) and 1930 (right), the first two years of the survey and eradication program. The size of the circle is a direct representation of the documented percent of infected trees per county (PPD incidence). A red, open circle means no PPD was detected. PPD incidence was 0-10.9\% and 0-10.5\% in 1929 and 1930, respectively. Data is derived from the Georgia State Board of Entomology Biennial Report of the State Entomologist for 1929-1930 Bulletin 75

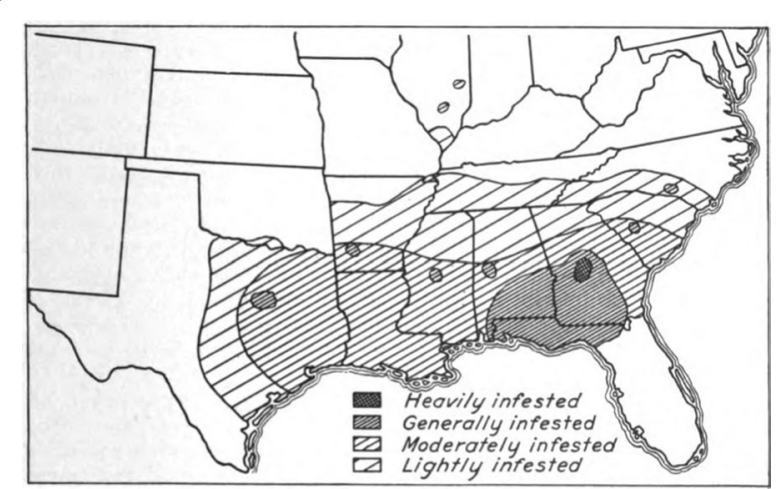

Fig. 10 Distribution of phony peach disease (caused by Xylella fastidiosa subspecies multiplex) in the United States on January 1, 1933 (from Hutchins 1933)

effect of Xf on its host indicate a much smaller number of species, so Xf is typically considered a commensalist (Sicard et al. 2018). Xf was first associated as a cause of plant disease in the Western Hemisphere when Pierce's Disease (PD) of grapevine was discovered by Newton B. Pierce in Southern California (Pierce 1892; Davis et al.

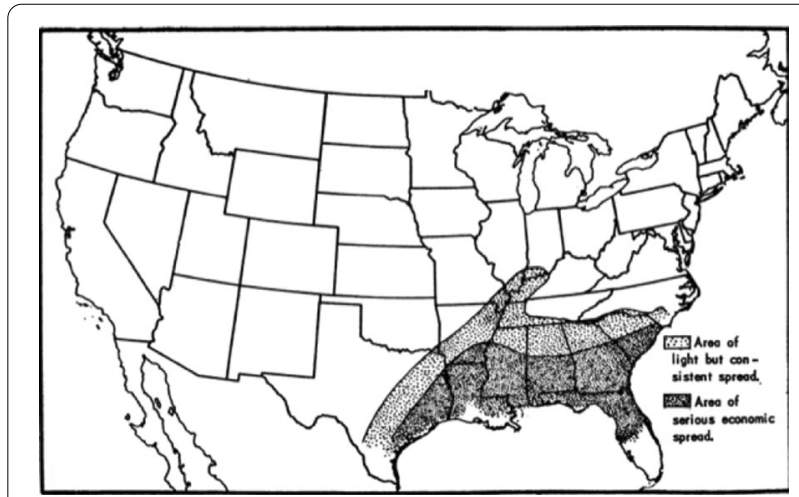

Fig. 11 Final distribution of Phony Peach Disease, caused by Xylella fastidiosa subsp. multiplex, in the United States (from Turner and Pollard 1959a)

1978; Wells et al. 1987; Sicard et al. 2018), although the causal agent was not known for some time. The bacterium was eventually described as gram-negative, fastidious, obligately aerobic and slow growing on selective media (Wells et al. 1987). Unlike other plant pathogenic bacteria, Xf does not have a type III secretion system, 


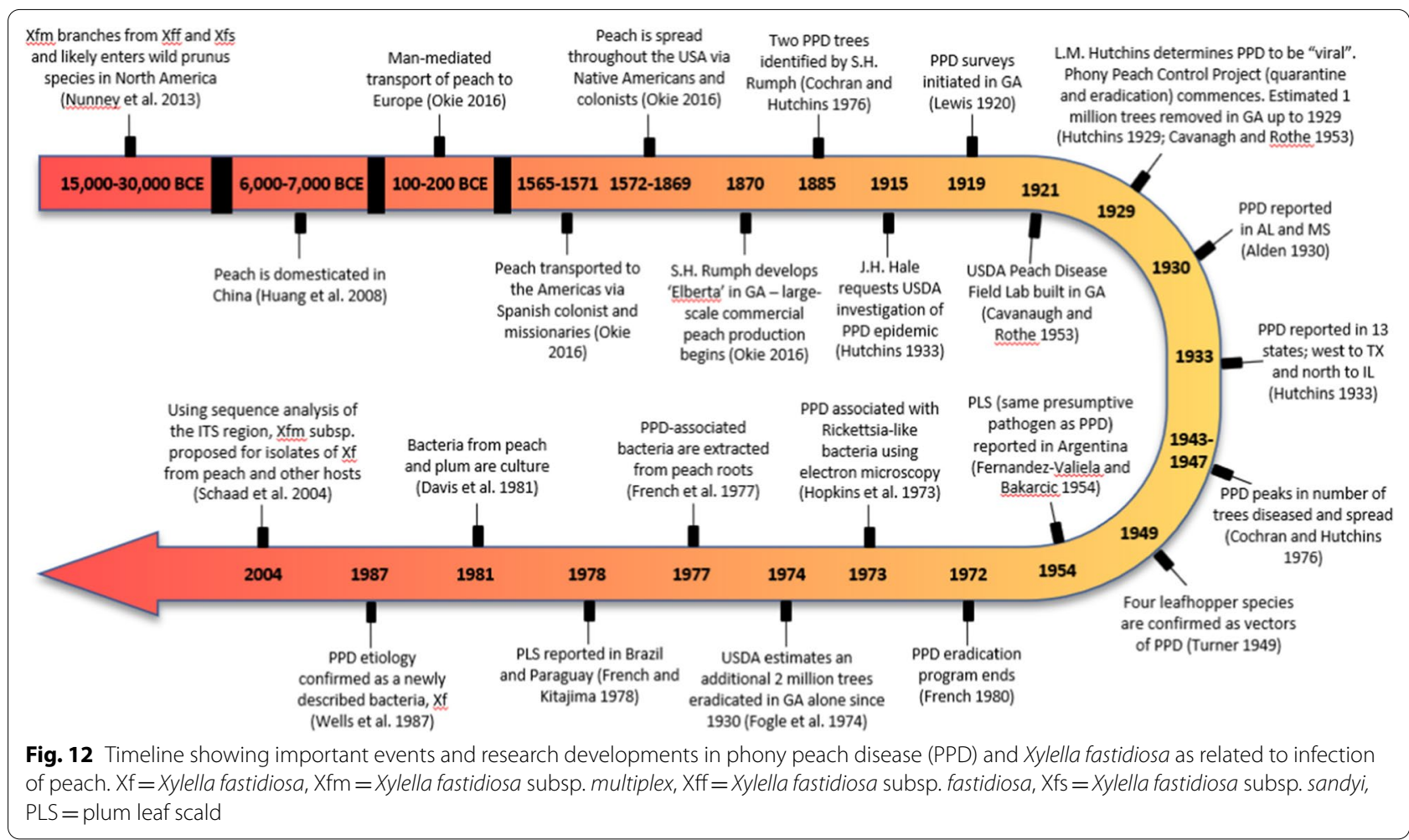

which has several functions including helping a pathogen colonize its host and survive in the host environment. Evidence suggests a type II secretion system is present in $\mathrm{Xf}$ because of the specific enzymes found to function in plant cell wall degradation (Janse and Obradovic 2010).

The bacterium that causes Xf-related diseases was initially referenced as a virus, because the causal agent could not be cultured or produce symptoms through inoculation, but the disease was transmissible via grafting (Pierce 1892; Hutchins 1928). In 1928, Hutchins "conclusively" determined PPD was caused by an infectious virus (Hutchins 1929). Almost 50 years later, Xf related diseases were associated with a rickettsia-like bacterium (RLB), due to the similarities that Xf and RLB share, including the typically rippled or furrowed cell walls (Moll and Martin 1974). Through the use of electron micrographs, the purported RLB was found in the xylem tissue of the host (Goheen et al. 1972). In 1973, a research group from the University of Florida and the USDA-ARS in College Station, Texas proposed that the RLB found in peach could be associated with PD of grape due to the similar symptoms in the xylem including the formation of gum pockets in vessels and other xylem cells and pitclosing membranes becoming discolored and swollen (Esau 1948; Hopkins et al. 1973). The symptoms suggest abnormal cambium behavior during initial growth in the spring (Esau 1948). Although they could not fully prove the theory due to failure to complete Koch's postulates (the organism could not be cultured), it prompted even more effort towards identifying the etiology of the two diseases in grape and peach, respectively.

Four years later, French et al. (1977) were able to extract the RLB from peach roots. Electron microscopy revealed bacteria of the same size and morphology as those previously identified in other plant species (Hopkins et al. 1973; Nyland et al. 1973). In 1981, the bacteria from peach and plum were observed via electron microscopy and small slender rods were found ranging in size of 0.3 to $0.4 \mu \mathrm{m}$ in width and 2.6 to $20 \mu \mathrm{m}$ in length. The rods appeared to have cell walls with ridges and furrows (Fig. 13A) (Davis et al. 1981). But it was not until 1987 when the causal agent of PD and PPD was identified and named as Xf (Fig. 13B) (Wells et al. 1987). In 2004, Schaad et al. (2004), using sequence analysis of the ITS region, proposed that PPD and PLS isolates, along with isolates from several other hosts, should be combined into a new subspecies, $X$. fastidiosa subsp. multiplex (Xfm).

\section{Diversity of Xylella fastidiosa in relation to PPD}

As mentioned previously, Xf colonizes or infects a broad range of plant species (over 350 identified), and causes economic losses in numerous susceptible, commercially grown crops (Almeida and Nunney 2015). Xf has been proposed to be primarily an endophyte because 


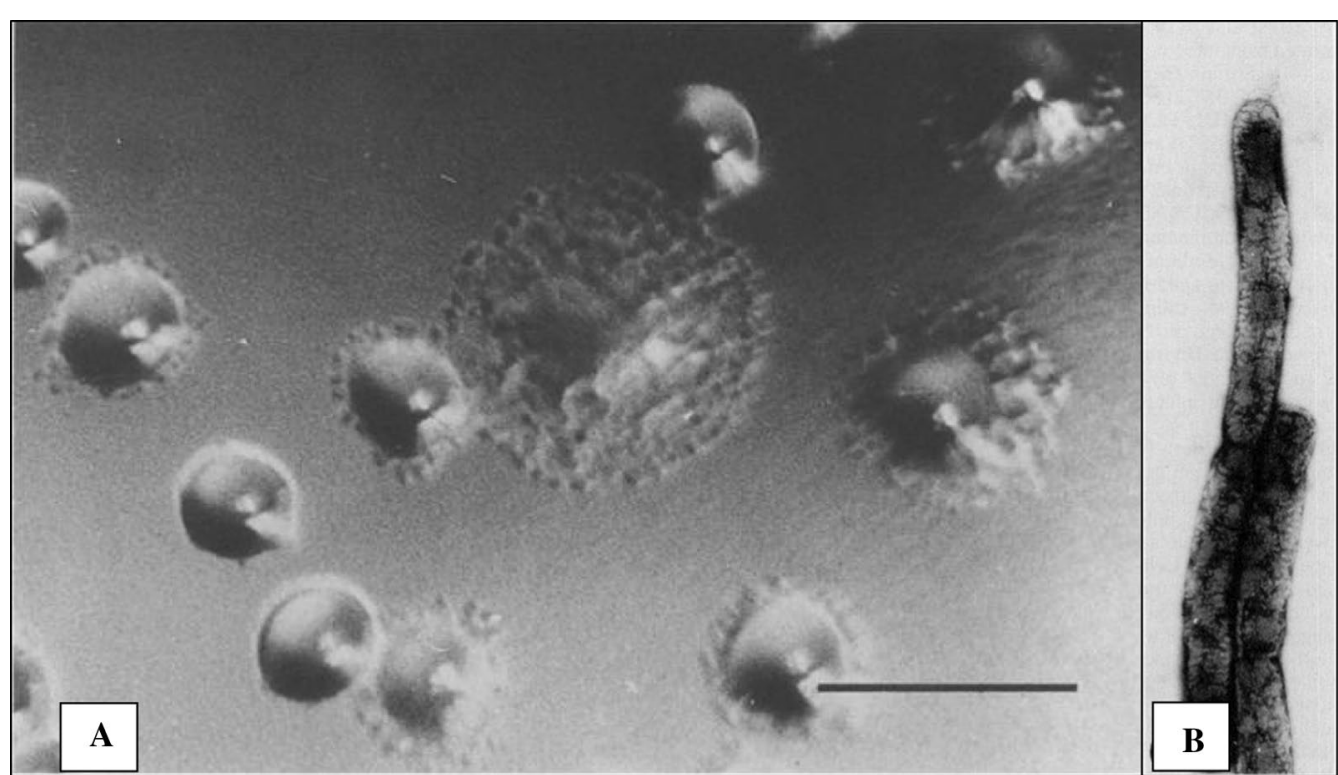

Fig. 13 A Colonies of Xylella fastidiosa subspecies multiplex (Xfm, cause of phony peach disease, PPD) bacterium on PW agar as seen by reflected light through a dissecting microscope (bar $=0.05 \mathrm{~mm}$ ) (Davis et al. 1981). B Negatively stained bacteria isolated from peach infected with Xfm. The rods are 0.25 to 0.27 by 1.2 to $2.4 \mu \mathrm{m}$ in size and have furrowed cell walls (magnification $\times 21,000$ ) (from Wells et al. 1987)

an interaction does not always result in disease (Chatterjee et al. 2008). Understanding the genetic diversity of $\mathrm{Xf}$ and relationships between subspecies is of upmost importance due to its wide host range and economic impact on commercially produced crops. Initial research on the molecular genetic diversity of PD strains and other Xf pathotypes was published in 2001 (Hendson et al. 2001), reporting a division of Xf species at a subspecies or pathovar level. There are currently six Xf subspecies determined by internal transcribed spacer (ITS) sequences and multilocus sequencing through partial sequences of 11 housekeeping genes (Yuan et al. 2010; Su et al. 2013; Jolley et al. 2018). The subspecies include fastidiosa, multiplex, pauca, sandyi, morus and tashke. $X$. fastidiosa subsp. fastidiosa was presumed to have originated in southern Central America (Nunney et al. 2010; Coletta-Filho et al. 2017) while subsp. multiplex (cause of PPD) is native to North America (Yuan et al. 2010). Xf is currently comprised of three clades: Clade 1 (pauca), Clade II (multiplex) and Clade III (fastidiosa, morus, and sandyi) (Denancé et al. 2019); tashke has yet to be assigned.

Varani et al. (2012) developed a database including all available sequenced genomes of various Xf strains. This is a web-accessible application to provide a resource of all sequence elements and their function within the $\mathrm{Xf}$ genomes. Genomic analyses can help us understand not only the pathogen's evolutionary history, but also potential pathogenicity (Varani et al. 2012). The use of genomics and metagenomics methods for the identification and classification of Xf pathogens is becoming mainstream. Vanhove et al. (2019) compared 72 Xf genomes to investigate differences among Xf subsp. fastidosa, pauca, and multiplex. Recombination is considered a primary driver of genetic diversity in Xf, and gene differences and recombination rates were identified among the main subspecies of Xf. The authors hypothesized that the high rate of recombination among Xf subsp. could result in continued spread through adaptation, with concomitant economic damage (Vanhove et al. 2019).

Host plant specialization can occur within $\mathrm{Xfm}$ as reported by Nunney et al. (2013). Based on molecular genetic analysis, peach isolates were host specific and independent of the "Oak" and "Almond" types of Xfm. Accurate identification of subspecies using molecular tools allows management strategies to be designed to minimize spread of the pathogens to new regions. This is important, as introduced bacteria can adapt to conditions and to new hosts in new regions, creating major phytosanitary concerns, an example being the impact on the olive industry due to the recent introduction of Xf subsp. pauca to Europe (Schneider et al. 2020). The current biological knowledge of $\mathrm{Xf}$ indicates that longdistance dispersal of infected insects or plants most likely involves man. Indeed, the spread of the bacterium on new hosts and in geographically isolated areas can only be explained through human intervention (Almeida and 
Nunney 2015), and PPD could theoretically be spread to wherever peach or other hosts are found.

\section{Detection of Xylella with special reference to peach}

Detection methods for the presence of $\mathrm{Xfm}$ in peach and other hosts have developed as technology has become more sophisticated. An acidified methanol and pure hydrochloric acid test was the earliest diagnostic for PPD (Hutchins 1933; Hutchins et al. 1951; Cavanagh and Rothe 1953). Root sections develop purple spots when infected with $\mathrm{Xfm}$, although trees symptomatic for years presented brown flecks in the root sections, precluding a need for the test (Hutchins 1933). Another method of detection is based on vacuum infiltration of $0.1 \mathrm{M} \mathrm{KOH}$ through the xylem. When viewed under a microscope, rod-shaped bacteria in the xylem vessels are visible (French 1974). Xfm is also detectable using electron microscopy (French et al. 1977), immunofluorescence (French et al. 1978), and enzyme-linked immunosorbent assay (ELISA) (Wells et al. 1981a, b). Although ELISA is used to detect $\mathrm{Xf}$ in grapevine (Baldi and La Porta 2017), it is rarely used in peach due to inconsistent results (Banks et al. 1999; T. Beckman, personal communication).

Most recently, diagnosis has relied on molecular detection methods including loop-mediated isothermal amplification (LAMP) (Harper et al. 2010), polymerase chain reaction (PCR) and quantitative PCR (qPCR), which provide accurate and efficient diagnosis. PCR primers have been developed that detect Xylella from the genus to sub-species level (Baldi and La Porta 2017). Genomebased PCR primers for the detection of Xf in grape were first developed in 1994 to compare the specificity and sensitivity of products to ELISA (Minsavage et al. 1994). A multiplex PCR protocol was developed later to detect the bacterium in field plants, vector insects, and asymptomatic infected plants using the 16rRNA and gyrase subunit B (gyrB) sequences (Rodrigues et al. 2003). Several other primer sets have been designed to differentiate between Xf strains and among strains from various host species (Banks et al. 1999; Francis et al. 2006). PCR primers were developed to determine the species and subspecies (multiplex) of $\mathrm{Xf}$ in peach by in silico comparison to sequence of subspecies of multiplex from oak and almond, and to sequence of subspecies fastidiosa, pauca and sandy $i$, and sequence of Xf from an unspecified subspecies (Chen et al. 2019). Of the primers tested, most detected more than one subspecies. For PCR diagnosis of Xylella in peach, roots provide the most reliable test tissue (Chen et al. 2019).

Techniques to increase sensitivity include nested-PCR (N-PCR) and quantitative real time PCR (qPCR), the latter allowing quantification of the pathogen (Baldi and $\mathrm{La}$
Porta 2017). Comparative analysis of several detection methods for Xf in blueberry was conducted; although LAMP was considered the most convenient for in-field detection, qPCR was able to differentiate between subspecies and genotype and quantify the bacteria in each sample (Bextine and Child 2007; Waliullah et al. 2019). Another recently deployed detection method is a rapid, field deployable test developed by Agdia, AmplifyRP $\mathrm{XRT}+$ for Xf, (Elkhart, IN, USA) (Macallister et al. 2020), and is comparable to qPCR for detection (Waliullah et al. 2019).

Spectral imaging has become an increasingly popular tool for precision agriculture and plant disease detection. Sensor-based methods can identify early physiological changes to the plant including leaf color, shape, and temperature (West et al. 2010). The sensors measure wavelengths of light that are either reflected or absorbed by green plants, which change due to many factors including growth vigor, water content and other chemical characteristics within the plant tissue (Xue and Su 2017). Multispectral and hyperspectral imaging are being widely used for disease detection and quantification (Mahlein 2016, Bock et al. 2020). In Italy, spectral imagining is being used to monitor spread of OQDS on olive (Zarco-Tejada et al. 2018; Di Nisio et al. 2020). Spectral imaging may be an efficient detection method for PPD. Potentially, spectral imaging cameras, mounted on an unmanned aerial vehicle (UAV), can cover a large area to quickly detect PPD trees in a commercial peach orchards; research is needed to test these technologies for detection of PPD.

\section{Isolation of Xfm from PPD peach trees}

Ability to culture a pathogen can be particularly valuable to the research process. Xf was first isolated from grape and was successfully cultured on a selective medium called Pierce's Disease 2 (PD2) (Davis et al. 1980). Other derivative media also supported growth of Xf (PD3, sugarcane (SC-20) and periwinkle wilt (PW) media (Davis et al. 1981). Isolation and culture of $\mathrm{Xf}$ in peach has been documented (Davis et al. 1981; Jennifer Randall, personal communication), but it is not an easy procedure and does not give consistent results. Although PPD and PD are caused by the same bacterium, Xf from grapevine is not as nutritionally fastidious as the strain from peach. Davis et al. (1981) found Xf from peach grew best on PW compared to the other media tested. PW medium contains glutamine and other ingredients from PD2 that may meet more of the nutritional requirements of $\mathrm{Xf}$ from peach (Davis et al. 1981). Xf from peach trees will also grow on buffered charcoal yeast extract (BCYE), CS-20 media, and in PW broth. PPD strains of Xf grown in PW broth have the slowest growth rates with a doubling time 
of 2 days, as compared to Xylella from grapevine which have a doubling time of $0.5-1.6$ days (Hopkins 1989).

Colony formation and morphology of Xfm collected from PPD and PLS varies depending on the growth medium. On BCYE, colonies were reported to be opalescent blue-white in color and attained diameters of 0.4 to $0.6 \mathrm{~mm}$ in 12 to 60 days (Wells et al. 1981b). On PW, colonies were characterized as opalescent white and ranged in morphology from circular, convex, and small with entire, undulate margins (Davis et al. 1981). Xfm does not form visible colonies until four to six weeks post plate streaking. Other strains of $\mathrm{Xf}$ are visible without magnification seven to fourteen days after streaking and aerobic incubation in the dark at 25 to $28^{\circ} \mathrm{C}$ (Raju et al. 1982; Janse and Obradovic 2010).

Isolation protocols have been developed for grape and blueberry, but these do not seem to be as effective for isolation of Xfm from peach (Davis et al. 1978, 1981). With peach, isolation has been from surface sterilized root or stem sections. Sap is squeezed from the freshly cut transverse surface and streaked onto culture media using an inoculation loop (Davis et al. 1981). Root was the most consistent tissue type for isolating $\mathrm{Xfm}$ from peach, but the bacteria may not be evenly distributed within the roots (Aldrich 1992; Chen et al. 2019). Xfm has also been isolated by crushing the tissue with an epi pestle, adding a buffer and sonicating the suspension prior to plating on PW media (J. Randall, personal communication; Davis et al. 1981). Culture of Xfm from peach remains a research barrier.

\section{Epidemiology of PPD}

The epidemiology of diseases caused by Xf are complex due to the interactions between the pathogen subspecies, various hosts, and vectors (EFSA 2018); the complex transmission and infection cycle is true of $\mathrm{Xfm}$ and PPD (Fig. 14). Epidemiological studies have concluded that diseases caused by Xf manifest in an aggregated pattern, which reflects vector movement through the crop (Gottwald et al. 1993; Roberto et al. 2002; Tubajika et al. 2004; Groves et al. 2005; Ferreira et al. 2016). Primary spread of $\mathrm{Xf}$ is from external inoculum sources, initially resulting in a random pattern of disease. Within the crop, the diseased plants subsequently serve as inoculum sources for secondary tree-to-tree spread, eventually resulting in an aggregated pattern of disease (Groves et al. 2005; Ferreira et al. 2016). Spatial analyses of almond leaf scorch (ALS, Groves et al. 2005) and plum leaf scorch (PLS, Ferreira et al. 2016), concluded both diseases had an aggregated distribution. A study by KenKnight (1961b) indicated a pronounced edge effect in young peach tree orchards, with a geometric decline in incidence of PPD from the orchard edge, although some aggregation of PPD was reported where an obstruction might affect downwind movement of vectors in an orchard. Fogle et al. (1974) reported that incidence of PPD increases in proportion to the age of trees and the number of diseased trees present, although no data was provided to support the observation. No other information is available on within-orchard spread of PPD.

Climate affects disease epidemiology, and should be factored in when considering potential spread of Xf. Based on the current distribution of Xf and projected future climate, management strategies can be designed to forecast spread into new areas. Godefroid et al. (2019) concluded temperature has an impact on the relationship between the host, bacterium, and vector. Their results indicate climate change will likely shift Xf risk areas, but more research is needed. As noted, the historic observations on spread and development of the PPD epidemic in the U.S. (Turner and Pollard 1959a) indicated a decrease in disease incidence at greater altitudes and latitudes, possibly due to colder winter conditions. Further research on spatial distribution of PPD and use of epidemiological models may contribute to filling the knowledge gaps we currently have of the pathogen and the disease.

\section{Acquisition of Xylella fastidiosa by insect vectors}

$\mathrm{Xf}$ inhabits the cuticular lining of the insect foregut to form a biofilm complex (Overall and Rebek 2017). The bacterium must be able to endure the xylem flow through ingestion due to the fast fluid flow during feeding (Silva et al. 2011). After cuticular attachment to the foregut, bacterial titer increases (Killiny and Almedia 2009). Although bacterial colonization of the insect has been studied primarily in vectors associated with grapevines, critical findings that could be of importance to spread of PPD include, colonization of the precibarium for successful inoculation of the insect, and the observation that size of the bacterial community in the foregut did not affect inoculation rate (Jackson et al. 2008; Daugherty et al. 2011).

\section{Vector transmission of Xylella fastidiosa}

In 1936, extensive entomological surveys identified the primary vectors of PPD in Georgia peach orchards (Turner and Pollard 1959b). The two primary natural vectors were Homalodisca vitripennis (Fig. 15), originally described as $H$. coagulata (Say), and Oncometopia orbona (F.), originally described as Oncometopia undata (F.) (Turner and Pollard 1959b); three other vectors were also identified: Graphocephala versuta (Say), H. insolita (Wlk.), and Cuerna costalis (F.) (Turner 1949). These hemipterans are in the family Cicadellidae, and are commonly called sharpshooters (Turner 1949). Both $H$. vitripennis and O. orbona are widely distributed in all states 


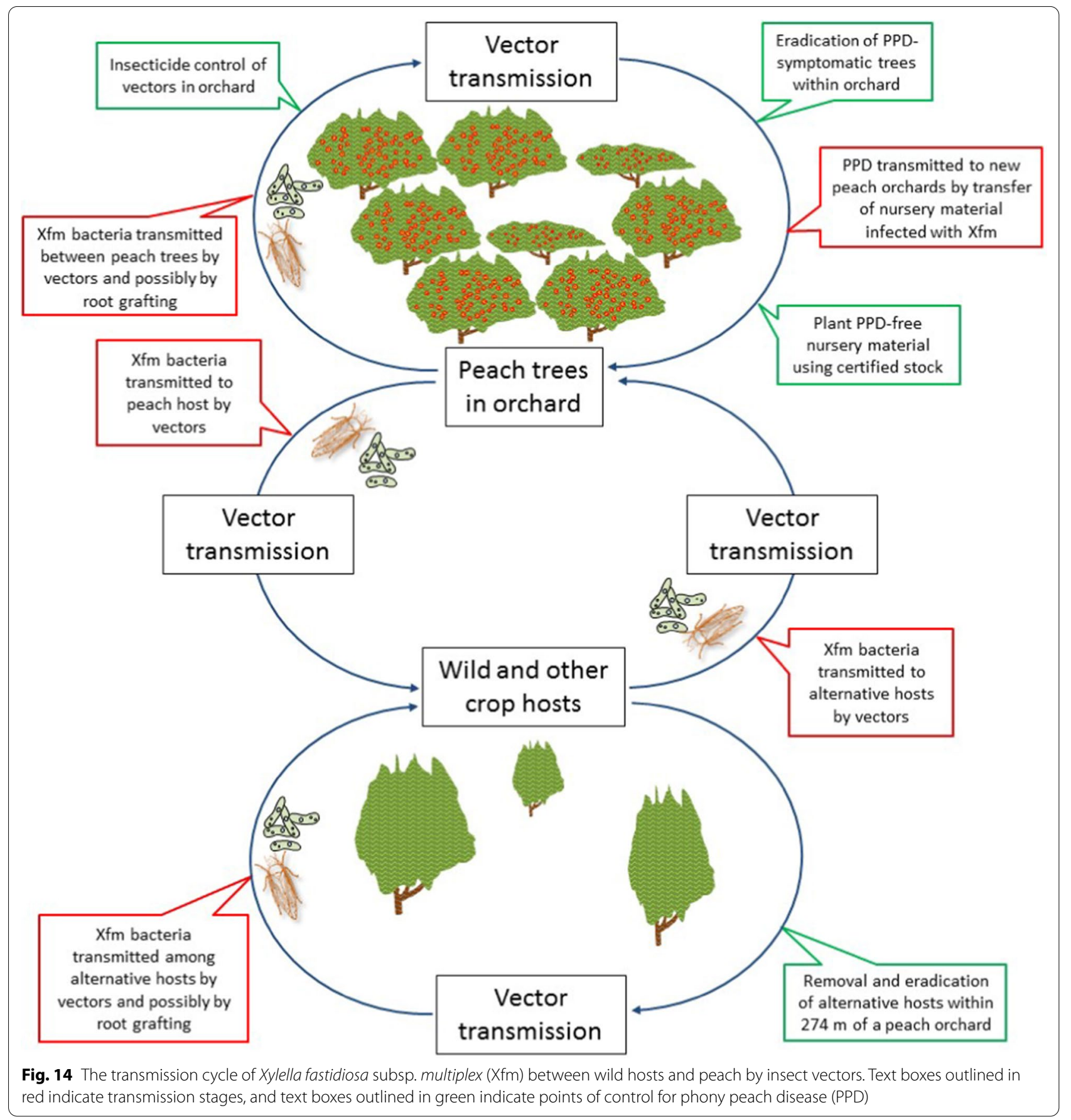

reported to have PPD. $H$. vitripennis is the predominant species found on peach in the southeastern U.S., while O. orbona tends to have a wider range from the southern tip of Florida extending north and northwest to Maryland, New York, Illinois and Indiana (Turner and Pollard 1959b). Comparative catches of adults determined $O$. orbona is more active on peach in the early spring, but $H$. vitripennis is the predominant species found during the summer and fall; it was further concluded that spread of PPD occurs between May 1 and August 31, with most transmission occurring in June and July (Turner and Pollard 1959b). Other studies in northern Florida indicated $H$. vitripennis was most prevalent in peaches in mid-summer compared to the fall. Differences between studies could be due to several factors including change of activity or mortality within habitats or increased 


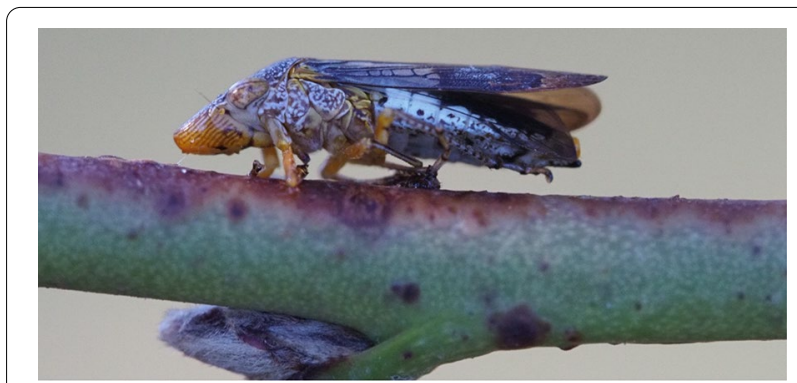

Fig. 15 Homalodisca vitripennis, the glassy-winged sharpshooter-a primary vector of Xylella fastidiosa subsp. multiplex in peach (photo courtesy of Brett Blaauw; University of Georgia Entomology Department)

population size with limited breeding sites near wooded areas (Ball 1979). Movement of the sharpshooter vectors was also dependent on alternative hosts outside the orchard, including wild native plums and other Prunus species. PPD incidence reportedly decreased when wild host eradication resulted in a greater distance from the edges of the peach orchards to potential sources of inoculum (KenKnight 1961a).

All species that transmit Xfm to peach are characterized as xylem-feeders, critical to the transmission of the pathogen. The transmission tests conducted in the 1940 s and 50s accurately determined the insect species capable of transmitting PPD, although PPD was thought to be caused by a virus at the time. Turner and Pollard (1959a) stated that the "virus" was persistent, had a latent period in the insect of at least eight days, but may extend to twenty days, and nymphs were able to acquire it and infect peach trees. Results of new research has contradicted these statements: sharpshooters do not have transovarial transmission due to nymphs shedding their cuticle, and the bacterium does not have a latent period in the vector (Janse and Obradovic 2010). These characteristics suggest that after a sharpshooter vector feeds on an infected plant, the foregut is the site where the bacteria are introduced into the insect (Purcell 1987).

Vectors utilize a probing behavior to transmit the bacteria by feeding on young host tissue as opposed to older growth. In a 1983 field study, $H$. vitripennis and $H$. insolita fed on diseased and healthy peach shoots, although they preferred healthy plants (Mizell and French 1987). A similar observation was made by Daugherty and colleagues on grapevines, in that the insects were more likely to choose healthy over diseased vines (Daugherty et al. 2011). During exploratory probing the vectors extract sap and can egest again for another sampling probe. Once the vector is finished with sampling, the precibarial valve will allow fluid to be ingested into the pump chamber where it is transported by the esophagus to the midgut (Almeida et al. 2005).

\section{Colonization of the xylem by Xylella fastidiosa}

Xylem vessels are characterized by thick walls that provide strength to support the high volume and rate of water and nutrient transportation. Xylem sap moves with the water potential gradient from a higher to lower potential. When a sharpshooter or spittle bug probes young host tissue, the piercing mouthparts draw xylem fluid in through utilization of a noncirculative mechanism and secrete saliva into the plant, when transmission occurs (Killiny and Almeida 2014). Xf colonizes the xylem vessel wall of the plants through formation of a biofilm, an important process for surface attachment of the bacteria that has been associated with virulence (Danhorn and Fuqua 2007; Rapicavoli et al. 2018). Killiny and Almeida (2014) determined an association between transmission of the bacteria to a plant when biofilm formation occurs within the insect foregut. Once transmission to the host occurs, $\mathrm{Xf}$ can enter into either of two states, an exploratory (or motile) state, or an insectacquirable state, meaning the bacteria is adhesive (Rapicavoli et al. 2018). For systemic infection, the motile state must occur for further xylem colonization. Xf produces outer membrane vesicles, which have been determined to obstruct attachment to xylem surfaces. This finding suggests the vesicles serve as a preventative measure against attachment when in the motile state.

Colonization of a host plant by Xf has been most studied in grapevines (Hill and Purcell 1995; Hopkins 2005). Xylem vessels are connected via scalariform bordered pits that separate pit membranes from each other. These pit membranes are primarily composed of plant cell wall material including cellulose and pectin (Rapicavoli et al. 2018). Mollenhauer and Hopkins (1974) found the Xylella bacterium is too large to passively move through the pit membrane pores that primarily allow only water and solutes with a particle size less than $20 \mathrm{~nm}$ in diameter (Stevenson et al. 2004). For further colonization of the xylem, Xf enters into vessels and degrades the pit membrane (Newman et al. 2004). Although this is the primary form of systemic movement, the bacterium also uses a long type IV pili for twitching motility (Janse and Obradovic 2010). The type IV pili structure enables bacteria to move against the flow of the xylem sap (De La Fuente et al. 2007).

In peach with PPD, the characteristic dwarfing of new growth is thought to be caused by the bacteria's interference with endogenous growth regulator activity (French and Stassi 1978; French 1980). Normal peach tree shoot growth in a season would average 0.8 to $0.9 \mathrm{~m}$, but 
infected trees will average one third of this growth in a season (Neal 1920). Not only is there a growth regulator imbalance in phony peach trees, but the leaf gas exchange, net $\mathrm{CO}_{2}$, and transpiration rates are reduced in infected trees. Andersen and French (1987) determined that midday leaf conductance was only mildly reduced in PPD trees (15 to $25 \%$ less compared to healthy trees). Although leaf-water potential and stem hydraulic conductivity were found to be lower in infected trees compared to healthy trees in some studies, suggesting direct evidence linking water stress with disease symptoms caused by Xf in peach (Evert and Mullinix 1983; Evert 1987), Andersen and French (1987) did not find a difference in hydraulic conductance between PPD and healthy trees, and they did not agree with the hypothesis of $\mathrm{Xf}$ plugging the xylem being the sole cause of PPD symptoms. They suggested more research is needed to determine how $\mathrm{Xf}$ is altering plant metabolism.

\section{Host range of Xylella fastidiosa in relation to PPD}

As noted, Xf has a host range of more than 350 species, but in most of these hosts the bacteria exists as an endophyte, causing few or no symptoms (Sicard et al. 2018; Almeida and Nunney 2015). However, alternative hosts are an important component of the epidemiology of Xf diseases, including PPD (Table 2).

Due to the asymptomatic endophytic state, the role of asymptomatic host species in or around a peach orchard is of upmost importance, as the alternative hosts can act as reservoirs of the pathogen and thus contribute to disease spread. A datasheet on Xf from CAB International compiles an extensive list of host plants and other plants affected by the bacterium classified as either crop or wild hosts (CABI 2020). Potential alternative hosts or reservoirs of Xfm occur in or near peach orchards in the U.S. and include wild native plums ( $P$. angustifolia), wild and domestic cherry species (P. serotina, $P$. avium) (Mizell et al. 2008; Olmo et al. 2017), other Prunus species (almond, apricot, Japanese apricot, David peach, Hortulan plum) (Cochran and Hutchins 1976), and Johnsongrass (Sorghum halepense) (Hutchins and Rue 1949; French 1976; Wells et al. 1980). Wild plum is often asymptomatic or has unclear symptoms (Turner and Pollard 1959a). Historically, growers were advised to eradicate all plum trees within $274 \mathrm{~m}$ of their orchards, although there was concern that wild plums more than $274 \mathrm{~m}$ away could serve as an inoculum source too (KenKnight 1961a). Johnsongrass is a weed commonly found in peach orchards throughout the Southeast region. Weaver et al. (1980) concluded there was most likely an association between the bacteria in Johnsongrass and PPD, suggesting the weed population may be a critical factor in spread of PPD.

\section{Man-mediated transfer of PPD including graft, budwood, seed and pruning transmission}

PPD and other Xf-mediated diseases can be transported by human intervention, including via vegetative propagation. Based on the known geographic range of Xylella subspecies and the biology of the bacterium, it is believed that long distance dispersal of Xf to new regions may be entirely by human intervention through the transfer of infected plant material or insects. Almeida and Nunney (2015) stated human-mediated dispersal is the primary source of Xf introductions. For example, the recent outbreak of Xf in olive in southern Italy is due to X. fastidiosa subsp. pauca, a subspecies initially identified in South America (Nunney et al. 2014). It is believed to have been imported on ornamental plants from Central America in 2013 (Giampetruzzi et al. 2017). Another similar introduction to the U.S. of Xylella fastidiosa subsp. fastidiosa (Xff) causing PD on grapevines, was likely from infected coffee plants shipped to the U.S. from Central America (Nunney et al. 2010; Almedia and Nunney 2015). Assuming that PLS and PPD are caused by the same bacterium, as host inoculation studies suggest (Wells et al. 1981a), then the PPD strain may have been transmitted to South America (Almeida and Nunney 2015). Nunes et al. (2003) determined that a Brazilian plum isolate was Xfm and was likely an introduction from the U.S.; similarly, reports of PLS in Argentina and Paraguay (Fernandez-Valiela and Bakarcic 1954; Kitajima et al. 1975; French and Kitajima 1978; French et al. 1978) are likely a result of humanmediated transfer (Almeida and Nunney 2015). Xfm is one of two subspecies that cause ALS (Chen et al. 2005) - Xff being the other subspecies. ALS has now been reported in the middle east in Iran (Amanifar et al. 2014) and Turkey (Guldur et al. 2005), but the subspecies were not determined in either case - but have a New World origin. More recently, multiple confirmed Xfm introductions in France, Italy, and Spain were hypothesized to have come from strains originating in California, U.S. (Landa et al. 2020). Should the Xfm strains that cause PPD now occur or be introduced to southern Europe and the Middle East, the peach industries in those regions could be severely compromised. Human-mediated introductions of subspecies of $\mathrm{Xf}$ into new regions can cause severe economic and social disruption; in the new hosts encountered there is often little resistance to the bacterium, with olive in southern Europe being a recent example (Sicard et al. 2018).

Initially, the causative agent of PPD, presumed to be viral, was reported as being confined to roots, as early studies indicated that the disease was not transmitted by buds or grafts from an infected tree. In 1933, budwood transmission tests indicated that PPD was not transmissible by budding (Hutchins 1933). However, healthy 
Table 2 Scientific and English common name(s) of Xylella fastidiosa subsp. multiplex hosts (from EPPO Global Database, 2021), Xylella fastidiosa subsp. multiplex (XYLEFM) (https://gd.eppo.int/taxon/XYLEFM/hosts)

\begin{tabular}{|c|c|}
\hline Scientific name & Common name \\
\hline Acacia dealbata & Mimosa, Silver Wattle, Silver Green Wattle \\
\hline Acacia saligna & $\begin{array}{l}\text { Coojong, Golden Wreath Wattle, Orange Wattle, Blue-Leafed Wattle, Western Australian Golden Wattle, Port } \\
\text { Jackson Wattle, Weeping Wattle, Golden Willow }\end{array}$ \\
\hline Acer pseudoplatanus & Great Maple, Plane Maple, Sycamore \\
\hline Anthyllis hermanniae & Lavender-Leaved Anthyllis \\
\hline Artemisia aborescens & Shrubby Wormwood, Tree Wormwood \\
\hline Artemisia sp. & $-^{\mathrm{a}}+1-0$ \\
\hline Asparagus acutifolius & Lesser Asparagus, Sharp-Leaved Asparagus \\
\hline Calicotome spinosa & Spiny Broom \\
\hline Calicotome villosa & Spiny Broom, Thorny Broom \\
\hline Carya illinoinensis & Pecan \\
\hline Cercis siliquastrum & Common Judas Tree, Judas Tree \\
\hline Cistus creticus & Grey Cistus, Pink Rockrose White-Leaved Rockrose \\
\hline Cistus monspeliensis & Narrow-Leaved Cistus \\
\hline Cistus salviifolius & Sage-Leaved Cistus, Sage-Leaved Rockrose \\
\hline Cistus $x$ incanus & 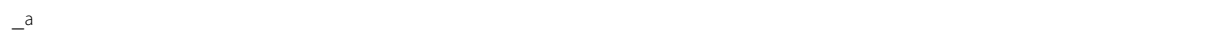 \\
\hline Convolvulus cneorum & Shrubby Convolvulus, Silver Bush \\
\hline Coprosma repens & $\begin{array}{l}\text { Mirror Bush, Looking-Glass Bush, New Zealand Laurel, Shiny Leaf, Tree Bedstraw, Taupata, Looking-Glass Plant, } \\
\text { Mirror Plant }\end{array}$ \\
\hline Coronilla valentina & Shrubby Scorpion Vetch \\
\hline Coronilla valentina subsp. glauca & Citrina \\
\hline Cytisus scoparius & Common Broom, Scottish Broom, English Broom, Broom \\
\hline Cytisus villosus & Hairy Broom \\
\hline Dimorphotheca ecklonis & African Daisy, Bedding Marigold, Blue-And-White Daisy-Bush, Van Staden's Daisy \\
\hline Elaeagnus angustifolia & Oleaster, Russian Olive, Trebizond Date, Wild Olive \\
\hline Erigeron karvinskianus & Mexican Daisy, Mexican Fleabane, Érigégon Des Murs \\
\hline Euryops chyrsanthemoides & Daisy Bush \\
\hline Euryops pectinatus & Golden Daisy Bush, Golden Euryops, Grey-Leaf Euryops, Yellow Busy Daisy \\
\hline Ficus carica & Common Fig, Fig \\
\hline Fraxinus angustifolia & Narrow-Leaved Ash, Southern Ash \\
\hline Genista corsica & Corsican Gorse \\
\hline Genista ephedroides & $-^{\mathrm{a}}+\quad-10$ \\
\hline Genista x spachiana & $-{ }^{\mathrm{a}}$ \\
\hline Grevillea juniperina & Juniper Grevillea, Juniper-Leaf Grevillea, Prickly Spider-Flower \\
\hline Hebe & $--^{\mathrm{a}}$ \\
\hline Hebe elliptica & $-{ }^{\mathrm{a}}$ \\
\hline Helichrysum italicum & Curry Plant, Italian Everlasting, White-Leaved Everlasting \\
\hline Helichrysum sp. & $--^{\mathrm{a}}$ \\
\hline Helichrysum stoechas & Flower Of Gold, Gold Everlasting, Mothwort, Shrubby Everlasting \\
\hline Ilex aquifolium & Common Holly, Holly, Variegated Holly, English Holly \\
\hline Lavandula angustifolia & Common Lavender, English Lavender, French Lavender, Garden Lavender \\
\hline Lavandula dentata & Fringed Lavender, Toothed Lavender \\
\hline Lavandula stoechas & French Lavender, Spanish Lavender, Topped Lavender \\
\hline Lavandula x heterophylla & $-{ }^{\mathrm{a}}$ \\
\hline Lavandula xintermedia & $--^{\mathrm{a}}$ \\
\hline Lonicera japonica & Japanese Honeysuckle \\
\hline Medicago arborea & Tree Alfalfa, Tree Medick \\
\hline Medicago sativa & Purple Medick, Lucerne, Alfalfa \\
\hline Metrosideros excelsa & New Zealand Christmas Tree \\
\hline
\end{tabular}


Table 2 (continued)

\begin{tabular}{|c|c|}
\hline Scientific name & Common name \\
\hline Myrtus communis & Common Myrtle, True Myrtle, Myrtle \\
\hline Olea europaea & Common Olive, Olive \\
\hline Pelargonium graveolens & Rose Geranium, Sweet-Scented Geranium \\
\hline Phagnalon saxatile & $-{ }^{\mathrm{a}}$ \\
\hline Phlomis fruticosa & Jerusalem Sage, Tree Sage, Wild Mullein \\
\hline Pistacia vera & Pitasche Nut, Pistachio, Pistachio Nut \\
\hline Polygala myrtifolia & Sweet Pea-Shrub, Myrtleleaf Milkwort, September Bush \\
\hline Prunus armeniaca & Apricot \\
\hline Prunus cerasifera & Cherry Plum, Myrobalan Plum \\
\hline Prunus cerasus & Amarello Cherry, Dwarf Cherry, Sour Cherry, Tart Cherry \\
\hline Prunus domestica & European Plum, Garden Plum, Plum \\
\hline Prunus dulcis & Almond, Sweet Almond \\
\hline Prunus persica & Peach \\
\hline Quercus suber & Cork Oak \\
\hline Rhamnus alaternus & Barren Privet, Italian Buckthorn, Mediterranean Buckthorn \\
\hline Robinia pseudoacacia & Black Locust, False Acacia, Locust, Locust Tree, Robinia \\
\hline Rosa canina & Briar Rose, Common Briar, Dog Rose \\
\hline Rosa Cluster-flowered bush hybrids & $-{ }^{\mathrm{a}}$ \\
\hline Salvia rosmarinus & Garden Rosemary, Moorwort, Rosemary \\
\hline Santolina chamaecyparissus & Cotton Lavender, Cypress Cotton, Cypress Lavender Cotton, Lavender Cotton \\
\hline Spartium junceum & Rush Broom, Spanish Broom, Weaver's Broom \\
\hline Strelitzia reginae & Crane Flower, Queen's Bird-Of-Paradise \\
\hline Ulexeuropaeus & Common Furze, Corse, Furze, Gorse, Whin \\
\hline Ulexminor & Dwarf Furze, Dwarf Gorse \\
\hline Vaccinium virgatum & Rabbit-Eye Blueberry, Smallflower Blueberry \\
\hline Vitis aestivalis & Bunch Grape, Pigeon Grape, Summer Grape \\
\hline Westringia fruticosa & Australian Rosemary, Coastal Rosemary \\
\hline
\end{tabular}

${ }^{a}$ English common name was not provided by EPPO Global Database

scions or roots that were grafted to PPD-infected roots readily developed PPD (Smith 1941). Later, PPD was determined to be easily transmitted when either infected peach roots were grafted to healthy roots, or when diseased peach scions or root pieces were grafted into the branches of peach trees (Hutchins et al. 1953; Cochran and Hutchins 1976). Hutchins (1939) determined that the survival of the agent was limited to the parenchyma of the woody cylinder which was demonstrated when bark from diseased roots was grafted to healthy roots and transmission of PPD did not occur. Heel-spur scions were also reported to be effective for PPD transmission to the canopy of trees because of the quick union formation keeping the agent-infected wood alive (Cochran et al. 1953). The causal agent was noted to move rapidly to the roots even if only one lateral branch was infected through inoculation, but when roots were inoculated, the agent did not move to the upper parts of the peach trees. It was speculated that distribution of the causal agent was more uniform and survival was enhanced in the roots compared to branches and leaves in the aboveground parts of peach trees due to the large amount of living wood in the root system that can support a greater pathogen load (Cochran and Hutchins 1976). Root grafting was demonstrated to be a primary means of disease transmission from tree to tree. It was noted several times that when root-graft connections were present, the disease was transmissible, but if shoot-to-shoot grafts were present, the disease was not (Hutchins 1933). Transmission of Xf through natural root grafting has also been demonstrated in sweet orange plants (He et al. 2000).

In 1920, nurseries in Georgia were under investigation due to their potential source for spread of PPD (Neal 1920). It was recommended that peach growers be particularly careful selecting budwood from areas with a high incidence of PPD to avoid disseminating diseased trees to other locations. Concerns were also raised regarding possible seed transmission. More than 1000 seedlings grown from symptomatic phony tree seeds were budded to a commercial variety to test for seed 
transmission. No trees became PPD symptomatic, suggesting seed from infected trees did not transfer PPD (Hutchins 1933). There is no recently published research on transmission of $\mathrm{Xf}$ from seed in peach, but this early study suggests Xf transmission via seed may be unlikely. However, with the advent of more modern molecular techniques, seed transmission of PPD should be revisited.

Pruning is common in orchard and vineyard maintenance, and can be a means of pathogen dispersal. If pruning tools are not sanitized or disinfested, bacterial diseases like fire blight of apple and pear, caused by Erwinia amylovora, (Choi et al. 2019) and PD of grapevine (Krell et al. 2007) can be spread from plant to plant. There is no evidence of transmission of $\mathrm{Xfm}$ in peach from pruning. Transmission via pruning is unlikely due to the low bacterial titer typically found in the peach shoots (Chen et al. 2019), but research should be conducted to validate this hypothesis. Also, the unlikely survival of $\mathrm{Xfm}$ outside the host may be another factor minimizing risk of transfer by pruning, but has not been studied either.

\section{Management of Xylella-induced diseases with special reference to PPD}

Various disease management strategies are applied in other crops affected by Xf including blueberry, pecan, grape, olive and plum. Strategies include phytosanitary regulation, identification of rootstocks and cultivars less susceptible to the bacteria, removal of infected plants, and control of vectors through insecticide applications (Ogawa et al. 1995; Krewer et al. 2002; Ren and Lu 2002; Chang et al. 2009; Cousins and Goolsby 2011; Sanderlin 2015; Dalbó et al. 2016; Brannen et al. 2016; Schneider et al. 2020). A review by Kyrkou et al. (2018) provided an excellent account of the methods either researched or used to control Xff causing Pierce's disease of grape. Many of the prophylactic and therapeutic approaches described therein are relevant to PPD.

\section{Treatment and sourcing of propagation material}

One potentially useful disease management strategy is hot water treatment to kill $\mathrm{Xf}$ in propagation material. Clean propagation wood is an effective way of preventing the spread of PD to new areas (Hopkins 2005). To eliminate transmission of $\mathrm{Xf}$ in pecan, scion wood is submerged in hot water $\left(46^{\circ} \mathrm{C}\right)$ for 30 min prior to grafting (Sanderlin and Melanson 2008). Although hot water treatment was referenced in the late 1930 s to be an effective strategy to inactivate Xf in dormant nursery peach trees (Hutchins and Rue 1939), the method should be revisited. Microwaves combined with the use of microwave absorber nanoparticles were shown to reduce Xf positivity in pecan shoots, although the propagation material was not tested to confirm that the shoots were disease free if grafted (Hilton et al. 2021). These strategies should be explored as potential PPD management options to ensure clean, disease free peach nursery material.

\section{Removal of PPD-infected trees and alternative hosts}

Current control efforts are mainly focused on preventing the spread of the disease within an orchard which typically involves removal of symptomatic trees (Fogle et al. 1974). In the past, growers in Georgia have eradicated wild Chickasaw plum in the area surrounding peach orchards, as it serves as an inoculum reservoir (Fogle et al. 1974; Welsh 1976; Weaver et al. 1980). Orchard floor management is a further control option to reduce potential inoculum sources; for example, Johnsongrass is a potential source of Xfm (Weaver et al. 1980). In 1962, The USDA-ARS prepared an informational leaflet documenting PPD control measures. As noted, it was suggested one year prior to planting, wild-plum and peach trees should be destroyed within $274 \mathrm{~m}$ of a new site (USDA-ARS 1962).

\section{Control of the vectors}

Work has been conducted to study the effects of vector biological control agents including use of several species of Gonatocerus to parasitize glassy-winged sharpshooter eggs (Triapitsyn and Phillips 2000; Triapitsyn et al. 2002), and entomopathogenic fungi, specifically Hirsutella sp. (Conklin and Mizell 2013). Imidacloprid, a systemic neonicotinoid insecticide, slows development of epidemics of PD in grapevine plantings (Krewer et al. 2002), and was used in peach to determine if a soil drench at planting followed by consecutive applications for five seasons thereafter would reduce incidence or control PPD. Whereas $13.1 \%$ of the trees treated with imidacloprid developed symptoms of PPD, 71.4\% of the untreated trees developed PPD (Dutcher et al. 2005), indicating that annual use of imidacloprid could provide a useful level of control. Resistance to insecticides is a concern when applying chemicals, but there is little cross-resistance with older insecticide classes (Nauen and Denholm 2005; Denholm et al. 2002). To ensure continued efficacy of imidacloprid, resistance management strategies should be implemented including limiting the number of applications per season and incorporating other modes of action in the spray program (Nauen and Denholm 2005). The limited management options available for PPD in southeastern peach orchards is in part due to the lack 
of knowledge regarding the biology, epidemiology, and prevalence of the disease.

\section{Biocontrol of Xylella based on competitive exclusion and the use of phages}

In 1992, Hopkins discovered a non-pathogenic strain of Xf, EB92-1. When grapevines were inoculated with EB92-1 and challenged with a pathogenic strain of Xf, there was a reduction in symptoms of PD (Hopkins 2005). Inoculating peach with the EB92-1 strain of Xf could result in similar protection against pathogenic strains of Xfm, but the research has yet to be conducted.

Phages have been tested that infect and are virulent against Xf (Ahern et al. 2014). In later experiments it was demonstrated that a cocktail of four phages when inoculated into grapevine either before or after Xff provided complete protection against infection (Das et al. 2015). Although in the exploratory phase, this approach might prove effective in controlling PPD.

\section{Effect of antimicrobials against Xylella}

Antimicrobials have not been tested against Xfm causing PPD but have been screened against Xf from other hosts. Various antimicrobials have been screened including antibiotics and antimicrobial peptides, some of which have been found to be effective (Kuzina et al. 2006). Recently, in vitro experiments determined antimicrobial effects of peptide conjugates derived from BP100, with exposure resulting in Xf cell death due to the lytic effects of the peptides, and an induction of the viable but nonculturable state (Santiago et al. 2018). Various essential oils were screened by Baró et al. (2020) and they determined that sandalwood and patchouli essential oils had antibacterial action and thus promise as a natural antimicrobial against Xf. Much further research is needed to screen additional antimicrobials, and also once identified, to develop methods of delivery that will control Xf but not harm the host.

\section{Host resistance}

Losses due to Xf-incited diseases can vary by genotype in some commodities, which indicates that breeding for resistance/tolerance is possible (Sanderlin and Heyderich-Alger 2003; Sisterson et al. 2008; Ledbetter and Rodger 2009; Rashed et al. 2013; Dalbó et al. 2016; Saponari et al. 2019). Recently, a screening program was put in place to search for resistance to $\mathrm{Xf}$ in olive trees in Europe (Saponari et al. 2019).

However, most varieties of peach grown in middle Georgia in the 1920s were found to be susceptible to PPD (Neal 1920). The most prevalent varieties planted and those infected with PPD included 'Elberta', 'Belle of
Georgia,' 'Hiley Belle', 'J. H. Hale' and 'Mayflower.' 'Elberta' was thought to be more susceptible, but this hypothesis was biased due to 'Elberta' being the most widely planted variety in central Georgia (Neal 1920). Rootstocks were studied in hopes of finding a resistant stock for commercial use, but none were found (Savage 1983). It was noted in 1976 that seedlings of Japanese apricot, Mexican plum, and Chickasaw plum were also susceptible when grafted with root pieces from PPD symptomatic trees (Cochran and Hutchins 1976), precluding their use as a source of resistance. A total of 48 Prunus genotypes were tested for resistance to Xf based on symptomology post infection. The authors concluded resistance was controlled and heritable by recessive genes (Norton et al. 1994). No recent research has been conducted to investigate genetic modification or traditional breeding for PPD resistance; nor have modern varieties of peach and peach rootstocks been screened for resistance to PPD.

Recently, scientists in Brazil identified a set of defenserelated genes that could play a role in resistance to $\mathrm{Xf}$ in Citrus sp. (Mauricio et al. 2019). Biotechnology may offer a route to host resistance. Dandekar et al. (2012) proposed genetically engineering grape cultivars to express antimicrobial proteins for suppression of Xff.

\section{Quarantine regulations and eradication of PPD}

The United States Peach Disease Field Laboratory was established in 1921 in Fort Valley, Georgia, at least in part to conduct research on PPD (Cavanaugh and Rothe 1953; Okie 2016). In 1929, and as a result of the PPD epidemic, Plant Quarantine No. 67 was instated to prohibit shipments of peach nursery stock from areas where PPD was present within $1.6 \mathrm{~km}$ of a nursery (Fogle et al. 1974; Savage 1983). Plant material from nectarine, or any material grafted or budded on peach or nectarine roots from states with PPD was added to Plant Quarantine No. 67 for prohibited distribution in 1931 (Hutchins et al. 1951). Numerous states, including California, initiated quarantines that barred import of trees from any state in which PPD was reported (Smith 1941), and to date, phony peach has not been reported in California, even though it is the largest producer of peaches in the U.S. In conjunction with the nursery quarantine program, local inspection surveys were conducted in commercial and home peach orchards during the late 1920s and early 1930s in an attempt to eradicate PPD. Surveys were conducted in Georgia orchards having 500 or more trees. As of 1931, a total of 89 counties had been surveyed and PPD had been found on peach trees in 1165 and 746 commercial and home orchards, respectively (Georgia State Board of Entomology 1931). The Federal-State cooperative program for systematic survey and removal of infected peach trees was instated, and the local restrictions were 
found to be successful against PPD in the southeastern U.S. (Cochran and Hutchins 1976). But in 1972, federal budget cuts resulted in both programs being discontinued, and as stated previously, Florida and Georgia had serious PPD outbreaks (French 1980).

\section{Future research needs on PPD}

Although research on PPD was continuous from 1919 to the 1980s (Lewis 1919; Neal 1920; Hutchins 1933; Turner and Pollard 1959a; Cochran and Hutchins 1976; French and Stassi 1978; Davis et al. 1981), there has been little foundational research on the disease in the last 50 years that can provide a basis for updated management of PPD (Hutchins 1933; Esau 1948; Turner 1949; Turner and Pollard 1959a; Hopkins et al. 1973; Wells et al. 1980; Savage 1983). There are several areas where research will aid our understanding and eventual management of the disease.

- Removal of infected trees is a primary management strategy. Detection usually relies on identification of symptoms by a trained scout, but PPD is initially difficult to detect visually due to the long latent period and the ambiguous nature of some of the symptoms that may be confused with Armillaria and Phytopthora root rots (Ogawa et al. 1995); a PPD tree that is not removed remains as a source of further infections. There is no information on the accuracy, reliability or inter- or intra-rater variability of scouting for detecting PPD. Thus, knowledge of error in visual detection of PPD will allow better training of scouts and more effective removal of infected trees, reducing the epidemic. Furthermore, sensor-based methods of detection of PPD have not been explored, including using multi- or hyper-spectral systems mounted on UAVs. These may be less error prone and provide earlier disease detection compared to visual methods.

- The use of chemical control has not been explored for the management of PPD since the late 1970s (French and Stassi 1978). Both plant defense inducers and plant growth regulators may be potential options for control of PPD. The unique shoot growth of peach trees infected with $\mathrm{Xfm}$ are likely a result of hormonal imbalance due to effect of the Xf pathogen, and experiments indicated gibberellic acid reversed symptoms of PPD on new growth on terminal buds (French and Stassi 1978). New phytohormone formulations and similar products including defense regulators have not been tested, so exploring the effect of these compounds could result in potential solutions for management of PPD in orchards.
- Resistant rootstock and/or scion material to manage PPD has been considered in only a few studies. Peach already has resistant or tolerant rootstocks and scions to specific pathogens (Okie and Pusey 1996). For example, 'Nemaguard' rootstock in peach, released in 1959, was marketed to be resistant to root-knot nematode damage (Savage 1983). With a goal of improved resistance to Xf in mind, resistance can be evaluated through screening germplasm to determine the best cultivar and rootstock options for a commercial grower, and to identify PPD-resistant or tolerant material that might be used in peach breeding programs.

- The prevalence of PPD is currently unknown in the Southeast U.S. PPD has not been surveyed for many years. In addition to conducting on-site surveys in Florida, Alabama, and South Carolina to update knowledge on disease prevalence, surveys in other states would flag disease presence where PPD has been reported historically.

- Though vector-mediated spread of PPD occurs, and root grafting has been demonstrated, further research is needed to understand the temporal and spatial distribution and sources of initial disease within orchards, and within-orchard spread of PPD applying modern epidemiological and entomological techniques. What is the vector efficiency of transmission? What insecticide treatments will minimize epidemic progression? What about control of alternative hosts within and outside orchards? Are there additional hosts to those already identified (e.g., pecan, blueberry) that may play a role in epidemiology of PPD? Is the strain of Xfm infecting almond in California able to infect peach, and vice versa?

- Metagenomics is a molecular tool used to analyze genomic information from DNA extracted from a sample. The use of metagenomics has become an increasingly popular technique to improve detection of bacteria in plant material, like Xf (Bonants et al. 2019). The technique has not been applied to peach and PPD. Metagenomics will allow Next Generation Sequencing (NGS) and assembly of Xfm genomes of PPD strains. The genome sequence can be analyzed to better understand population diversity, disease epidemiology, and potentially use of NGS for Xf detection.

Thus, further fundamental research is needed for a better understanding of the pathogen, vector, interactions, potential management options, and reducing the overall impact of PPD for future peach production in Georgia and elsewhere in the southeastern U.S. 


\section{Abbreviations}

ALS: Almond leaf scald; BCYE: Buffered charcoal yeast extract; CAB: Commonwealth Agriculture Bureau; ELISA: Enzyme-linked immunosorbent assay; ITS: Internal transcribed spacer; LAMP: Loop-mediated isothermal amplification; NGS: Next Generation Sequencing; OQDS: Olive quick decline syndrome; PCR: Polymerase chain reaction; PD: Pierce's disease; PD2: Pierce's disease 2; PLS: Plum leaf scald; PPD: Phony peach disease; PW: Periwinkle wilt; qPCR: Quantitative polymerase chain reaction; RLB: Rickettsia-like bacterium; UAV: Unmanned aerial vehicle; U.S.: United States; USDA: United States Department of Agriculture; Xf: Xylella fastidiosa; Xfm: Xylella fastidiosa subspecies multiplex.

\section{Acknowledgements}

CHB was funded by the USDA-ARS National Programs through CRIS project 6042-21220-014-00.

\section{Authors' contributions}

KAJ lead the writing of the manuscript. PMB and CHB contributed to the writing, revisions and made additions to the manuscript. All authors researched the literature and contributed to the figures and tables. All authors read and approved the final manuscript.

\section{Funding}

USDA-ARS National Programs through CRIS project 6042-21220-014-00.

\section{Availability of data and materials}

Not applicable.

\section{Declarations}

Ethics approval and consent to participate

Not applicable.

\section{Consent for publication}

Not applicable.

\section{Competing interests}

The authors declare that they have no competing interests.

\section{Author details}

1 Department of Plant Pathology, University of Georgia, 2105 Miller Plant Sciences Building, Athens, GA 30602, USA. ${ }^{2}$ United States Department of Agriculture-Agricultural Research Service-Southeastern Fruit and Tree Nut Research Laboratory, Byron, GA 31008, USA.

Received: 21 April 2021 Accepted: 21 June 2021

Published online: 20 July 2021

\section{References}

Ahern SJ, Das M, Bhowmick TS, Young R, Gonzalez CF. Characterization of novel virulent broad-host-range phages of Xylella fastidiosa and Xanthomonas. J Bacteriol. 2014;2014(196):459-71.

Alden $\mathrm{CH}$. Peach insects and diseases and how to control them. Georgia State Board of Entomology No. 71. 1930. p.16.

Alden CH. Peach Insects and Diseases. Georgia Department of Entomology Bulletin No. 80. 1939. p. 4-23.

Aldrich $\mathrm{JH}$. Distribution of Xylella fastidiosa within roots of peach. Plant Dis. 1992;76:885-8.

Almeida RPP, Nunney L. How do plant disease caused by Xylella fastidiosa emerge? Plant Dis. 2015;99(11):1457-67.

Almeida RPP, Blua MJ, Lopex JRS, Purcell AH. Vector transmission of Xylella fastidiosa: Applying fundamental knowledge to generate disease management strategies. Ann Entomol Soc Am. 2005;98(6):775-86.

Amanifar N, Taghavi M, Izadpanah K, Babaei G. Isolation and pathogenicity of Xylella fastidiosa from grapevine and almond in Iran. Phytopathol Mediterr. 2014;53:318-27.

Anderson HW. Phony peach. In: Diseases of Fruit Crops. New York: McGraw-Hill Book Company, Inc.; 1956. p. 281-4.
Andersen PC, French WJ. Biophysical characteristics of peach trees infected with phony peach disease. Physiol Mol Plant Pathol. 1987;31:25-40.

Baldi P, La Porta N. Xylella fastidiosa: Host range and advance in molecular identification techniques. Front Plant Sci. 2017;8(944):1-22.

Ball JC. Seasonal patterns of activity of adult leafhopper vectors of phony peach disease in north Florida. Environ Entomol. 1979;8(4):686-9.

Banks D, Albibi R, Chen JC, Lamikanra O, Jarret RL, Smith BJ. Specific detection of Xylella fastidiosa Pierce's disease strains. Curr Microbiol. 1999;39:85-8.

Baró A, Badosa E, Montesinos L, Feliu L, Planas M, Montesinos E, et al. Screening and identification of BP100 peptide conjugates active against Xylella fastidiosa using a viability-qPCR method. BMC Microbiol. 2020;20:229.

Bextine B, Child B. Xylella fastidiosa genotype differentiation by SYBR ${ }^{\circledR}$ Greenbased QRT-PCR. FEMS Microbiol Lett. 2007;276:48-54.

Bock CH, Barbedo JGA, Del Ponte EM, Bohnenkamp D, Mahlein A-K. From visual estimates to fully automated sensor-based measurements of plant disease severity: Status and challenges for improving accuracy. Phytopathology Research. 2020;2:9.

Bonants P, Griekspoor Y, Houwers I, Krijger M, van der Zouwen P, van der Lee TAJ, et al. Development and evaluation of a triplex taqman assay and next-generation sequence analysis for improved detection of Xylella in plant material. Plant Dis. 2019;103:645-55.

Brannen PM. Peach. In: Little EL, ediotor. 2018 Georgia Plant Disease Loss Estimates. Annual Publication; 2018. p. 102-11.

Brannen PM, Krewer G, Boland B, Horton D, Chang CJ. Bacterial leaf scorch of blueberry. UGA Extension, Circular 922. 2016. https://secure.caes.uga. edu/extension/publications/files/pdf/C\%20922 4.PDF.

Cavanagh $\mathrm{AE}$, Rothe $\mathrm{CH}$. Phony peach and peach mosaic. Plant Diseases, the Yearbook of Agriculture. 1953;1953:681-4.

Chang CJ, Donaldson R, Brannen P, Krewer G, Boland R. Bacterial leaf scorch, a new blueberry disease caused by Xylella fastidiosa. HortScience. 2009:44(2):413-7.

Chatterjee S, Almeida RPP, Lindow SE. Living in two worlds: the plant and insect lifestyles of Xylella fastidiosa. Phytopathology. 2008;46:243-71.

Chen J, Groves R, Civerolo EL, Viveros M, Freeman M, Zheng Y. Two Xylella fastidiosa genotypes associated with almond leaf scorch disease on the same location in California. Phytopathology. 2005;95:708-14.

Chen C, Bock CH, Brannen PM. Novel Primers and Sampling for PCR Detection of Xylella fastidiosa in Peach. Phytopathology. 2019;109:307-17.

Choi HJ, Kim YJ, Lim Y-J, Park DH. Survival of Erwinia amylovora on surfaces of materials used in orchards. Res Plant Dis. 2019;25(2):89-93.

Cochran LC, Hutchins LM. Phony. Virus Diseases and noninfectious disorders of stone fruits in North America. Handbook No. 437. United States Department of Agriculture. 1976 p. 96-103.

Cochran LC, Turner WF, Weinberger JH. Transmission of the phony disease virus from tops of certain affected peach and plum trees. Phytopathology. 1953:43:691-6

Coletta-Filho HD, Francisco CS, Lopes JRS, Muller C, Almeida RPP. Homologous recombination and Xylella fastidiosa host-pathogen associations in South America. Phytopathology. 2017;107:305-12.

Conklin T, Mizell III RF. Glassy-winged sharpshooter, Homalodisca vitripennis (coagulata) (Germar) (Insecta: Hemiptera: Cicadellidae: Cicadellinae). Entomology and Nematology Department, UF/ IFAS Extension. EENY274. 2013. Accessed 2020

Cornara C, Saponari M, Zeilinger AR, de Stradis A, Boscia D, Loconsole G, et al. Spittlebugs as vectors of Xylella fastidiosa in olive orchards in Italy. J Pest Sci. 2017:90:521-30.

Cousins P, Goolsby J. Grape rootstock variety influence on Pierce's disease symptoms in Chardonnay. CDFA Pierce's disease control program research symposium. 2011 p. 99.

Dalbó MA, Bruna ED, Nodari RO, Saifert L. Plum selections with total resistance to leaf scald (Xylella fastidiosa). Acta Horticulturae Int Soc Horticult Sci. 2016;1127:61-4.

Dandekar AM, Gouran H, Ibáñez AM, Uratsu SL, Agüero CB, McFarland S, et al. An engineered innate immune defense protects grapevines from Pierce Disease. Proc Natl Acad Sci USA. 2012;109(10):3721-5.

Danhorn T, Fuqua C. Biofilm formation by plant-associated bacteria. Annu Rev Microbiol. 2007:61:401-22.

Das M, Bhowmick TS, Ahern SJ, Young R, Gonzalez CF. Control of Pierce's disease by phage. Public Library of Science One. 2015;10:e0128902. 
Daugherty MP, Rashed A, Almeida RPP, Perring TM. Vector preference for hosts differing in infection status: Sharpshooter movement and Xylella fastidiosa transmission. Ecol Entomol. 2011;36:654-62.

Davis MJ, Purcell AH, Thomson ST. Pierce's disease of grapevine: Isolation of the causal bacterium. Science. 1978;199(4323):75-7.

Davis, MJ, Purcell AH, Thomson SV. Isolation media for the Pierce's disease bacterium. Phytopathology. 1980;70:425-9.

Davis MJ, French WJ, Schaad NW. Axenic culture of the bacteria associated with phony disease of peach and plum leaf scald. Curr Microbiol. 1981;6:309-14.

De La Fuente L, Burr TJ, Hoch HC. Mutations in type I and type IV pilus biosynthetic genes affect twitching motility rates in Xylella fastidiosa. $J$ Bacteriol. 2007:189:7507-10.

Denancé N, Briand M, Bagorieau R, Gaillard S, Jacques M. Identification of genetic relationships and subspecies signatures in Xylella fastidiosa. BMC Genomics. 2019;20(239):1-21.

Denholm I, Devine G, Foster S, Gorman K, Nauen R. Incidence and management of insecticide resistance to neonicotinoids. Proc Brighton Crop Prot Conf. 2002;1:161-8.

Di Nisio A, Adamo F, Acciani G, Attivissimo F. Fast detection of olive trees affected by Xylella fastidiosa from UAVs using multispectral imaging. Sensors. 2020;20(17):4915.

Dutcher JD, Krewer GW, Mullinix BG Jr. Imidacloprid insecticide slow development of phony peach and plum leaf scald. HortTechnology. 2005;15(3):642-5.

EFSA. Updated pest categorization of Xylella fastidiosa. Online publication. European Food Safety Authority. 2018 https://www.efsa.europa.eu/en/ efsajournal/pub/5357. Accessed 022021

Esau K. Anatomic effects of the viruses of Pierce's disease and phony peach. Hilgardia. 1948;18(12):423-81.

Evert DR. Influence of phony disease of peach on stem hydraulic conductivity and leaf xylem pressure potential. J Am Soc Horticult Sci. 1987:112:1032-6.

Evert DR, Mullinix BG Jr. Xylem water potential of peach trees infected with phony disease. HortScience. 1983;18:719-21.

Fernandez-Valiela, M.V. and M. Bakarcic. Nuevas enfermedades del ciruelo en el delta del Paraná, Argentina. In Informaciónes de Investigaciónes Agricolas (IDIA) No. 84, Instituto Nacional de Tecnologia Agropecuarias (INTA), Buenos Aires, Argentina. 1954. P. 2-6.

Ferreira GM, de Mascaro F, Dalla-Pria M, Ribeiro PJ, de Mio LL. Spatial analysis of plum leaf scald in São Paulo State Brazil. J Plant Pathol. 2016:98(3):511-8

Fogle HW, Keil HL, Smith WL, Mircetich SM, Cochran LC, Baker H. Phony Disease. Peach Production. USDA Agriculture Handbook 463. Washington, DC. 1974 pp. $78-79$

Francis M, Lin J, Cabrera-La Rosa J, Doddapaneni J, Civerolo EL. Genome-based $P C R$ primers for specific and sensitive detection and quantification of Xylella fastidiosa. Eur J Plant Pathol. 2006;115:203-13.

French WJ. A method for observing rickettsia like bacteria associated with phony peach disease. Phytopathology. 1974;64:260-1.

French WJ. The incidence of phony disease in wild plum trees as determined by histochemical and microscopic methods. Proc Florida State Horticult Soc. 1976:89:241-3.

French WJ. Phony Peach Disease. Proc Ann Conv Natl Peach Council. 1980:39:51-6.

French WJ, Kitajima EW. Occurrence of plum leaf scald in Brazil and Paraguay. Plant Dis Report. 1978:62:1035-8.

French WJ, Stassi DL. Response of phony infected peach trees to gibberellic acid. HortScience. 1978;13:158-9.

French WJ, Christie RG, Stassi DL. Recovery of RLB by vacuum infiltration of peach tissue affected with phony peach disease. Phytopathology. 1977:67:945-8.

French WJ, Stassi DS, Schaad NW. The use of immunofluorescence for the identification of phony peach bacterium. Phytopathology. 1978;68:1 106-8.

Georgia State Board of Entomology. Biennial Report of the State Entomologist for 1929-1930. Bulletin 75. May 1931. Phony Peach Diseases and Summary of Inspection for Phony Peach Disease, U.S. Department of Agriculture and Georgia State Board of Entomology Cooperating.

Georgia State Board of Entomology. Biennial Report for the State Entomologist for 1931-1932. Bulletin 77. June 1933. Special regulatory projects: phony peach disease, U.S. Department of Agriculture and Georgia State Board of Entomology Cooperating.

Giampetruzzi A, Saponari M, Almedia RPP, Essakhi S, Boscia D, Loconsole $\mathrm{G}$, et al. Complete genome sequence of the olive-infecting strain Xylella fastidiosa subsp pauca De Donno. Am Soc Microbiol Genome Announc. 2017;5(17):e00569-17.

Godefroid M, Cruaud A, Streito J, Rasplus J, Rossi J. Xylella fastidiosa: climate suitability of European continent. Nat Sci Rep. 2019;9(8844):1-10.

Goheen AC, Nyland G, Lowe SK. Association of a Rickettsialike organism with Pierce's disease of grapevines and alfalfa dwarf and heat therapy of the disease in grapevines. Phytopathology. 1972;63:341-5.

Gottwald TR, Gidtti FB, Santos JM, Carvalho AC. Preliminary spatial and temporal analysis of citrus variegated chlorosis (CVC) in São Paulo, Brazil. Int Organ Citrus Virol Conf Proc. 1993;12:12

Gould HP. Peach Growing. New York: The Macmillan Company; 1918.

Groves RL, Chen J, Civerolo EL. Spatial analysis of almond leaf scorch disease in San Joaquin valley of California: Factors affecting pathogen distribution and spread. Plant Dis. 2005;89:581-9.

Guldur ME, Caglar BK, Castellano MA, Ulnu L, Guran S, Yilmaz MA, et al. First report of almond leaf scorch in Turkey. J Plant Pathol. 2005;87:246.

Harper SJ, Ward LI, Clover GRG. Development of LAMP and real-time PCR methods for the rapid detection of Xylella fastidiosa for quarantine and field applications. Phytopathology. 2010;100(12):1282-8.

He CX, Li WB, Ayres AJ, Hartung JS, Miranda VS, Teixeira DC. Distribution of Xylella fastidiosa in citrus rootstocks and transmission of citrus variegated chlorosis between sweet orange plants through natural root grafts. Plant Dis. 2000:84:622-6.

Hendson M, Purcell AH, Chen D, Smart C, Guilhabert M, Kirkpatrick B. Genetic diversity of Pierce's disease strains and other pathotypes of Xylella fastidiosa. Appl Environ Microbiol. 2001;67(2):895-903.

Hill BL, Purcell AH. Acquisition and retention of Xylella fastidiosa by an efficient vector Graphocephala Atropunctata. Phytopathology. 1995;85:209-12.

Hilton A, Jeong M, Hsu JH, Cao F, Choi W, Wang X, et al. Thermal treatment using microwave irradiation for the phytosanitation of Xylella fastidiosa in pecan graftwood. Public Libr Sci One. 2021;16:e0244758.

Hopkins DL. Xylella fastidiosa: Xylem-limited bacterial pathogen of plants. Phytopathology. 1989;27:271-90.

Hopkins DL. Biological control of Pierce's disease in the vineyard with strains of Xylella fastidiosa benign to grapevine. Plant Dis. 2005;89:1349-52.

Hopkins DL, Mollenhauer HH, French WJ. Occurrence of a rickettsia-like bacterium in the xylem of peach trees with phony disease. Phytopathology. 1973:63:1422-3

Huang H, Cheng Z, Zhang Z, Wang Y. The Peach: Botany, Production and Uses. Layne DR and Bassi D, editors. CAB International, 2008. p. 37-60.

Hutchins LM. Peach orchards in Georgia menaced by phony disease. U.S. Dept. Agr. Yearb. Agr. 1928. p. 499-503.

Hutchins LM. Phony disease of the peach. Abstract Phytopathology. 1929;19:107.

Hutchins LM. Identification and control of phony disease of the peach. Georgia State Board Entomol Bull. 1933;78:1.

Hutchins LM. Apparent localization of phony disease virus in the woody cylinder. Abstr Phytopathol. 1939;29:12.

Hutchins LM, Rue JL. Promising results of heat treatments for inactivation of phony disease virus in dormant peach nursery trees. Abstr Phytopathol. 1939:29:12.

Hutchins LM, Rue JL. Natural spread of phony disease to apricot and plum. Phytopathology. 1949;39:661-7.

Hutchins LM, Cochran LC, Turner WF. Phony. Virus diseases and other disorders with viruslike symptoms of stone fruits in North America. Agriculture Handbook No. 10. United States Department of Agriculture; 1951. p. $17-25$.

Hutchins LM, Cochran LC, Turner WF, Weinberger JH. Phytopathology. 1953;43(12):691-6.

CABI, Xylella fastidiosa (Pierce's disease of grapevines). In: Invasive Species Compendium. Wllingford, UK: CAB Internation. 2020 www.cabi.org/isc. Accessed 1 April 2020

Jackson BC, Blua MJ, Bextine B. Impact of duration versus frequency of probing by Homalodisca vitripennis (Hemiptera: Cicadellidae) on inoculation of Xylella fastidiosa. J Econ Entomol. 2008;101:1122-6. 
Janse JD, Obradovic A. Xylella fastidiosa: Its biology, diagnosis, control and risks. J Plant Pathol. 2010;92(1, Supplement):S1.35-S1.48.

Jolley KA, Bray JE, Maiden MCJ. Open-access bacterial population genomics: BIGsDB software, the PubMLST.org website and their applications. Wellcome Open Res. 2018,3:124. https://pubmlst.org/organisms/xylel la-fastidiosa/: Accessed 1 Apr 2020

KenKnight G. Epidemiology of peach rosette virus in Prunus angustifolia. Plant Disease Reporter. 1961a;45(4):304-5.

KenKnight G. Spread of phony disease into Georgia peach orchards. Phytopathology. 1961b;51:345-9.

Killiny N, Almeida RPP. Host structural carbohydrates induces vector transmission of a bacterial plant pathogen. Proc Natl Acad Sci. 2009;106:22416-20.

Killiny N, Almeida RPP. Factors affecting the initial adhesion and retention of the plant pathogen Xylella fastidiosa in the foregut of an insect vector. Appl Environ Microbiol. 2014;75:521-8.

Kitajima EW, Bakarcic M, Fernandez-Valiela MV. Association of Rickettsialike bacteria with plum leaf scald disease. Phytopathology. 1975;65:476-9.

Krell RK, Boyd EA, Nay JE, Park Y-L, Perring TM. Mechanical and insect transmission of Xylella fastidiosa to Vitis vinifera. Am J Enol Vitic. 2007;58:211-6.

Krewer G, Dutcher JD, Chang CJ. Imidacloprid insecticide slows development of pierce's disease in bunch grapes. J Entomol Sci. 2002;37:101-12.

Kuzina LV, Miller TA, Cooksey DA. In vitro activities of antibiotics and antimicrobial peptides against the plant pathogenic bacterium Xylella fastidiosa. Lett Appl Microbiol. 2006:42:514-20.

Kyrkou I, Pusa T, Ellegaard-Jensen L, Sagot M-F, Hansen LH. Pierce's disease of grapevines: a review of control strategies and an outline of an epidemiological model. Front Microbiol. 2018;9:2141.

Landa BB, Castillo Al, Giampetruzzi A, Kahn A, Román-Écija M, Velasco-Amo MP, Navas-Cortés JA, Marco-Noales E, Barbé S, Moralejo E, Coletta-Filho HD, Saldarelli P, Saponari M, Almeida RPP. Emergence of a plant pathogen in Europe associated with multiple intercontinental introductions. Appl Environ Microbiol. 2020;86:e01521-e1619.

Ledbetter CA, Rogers EE. Differential susceptibility of Prunus germplasm (subgenus Amygdalus) to a California isolate of Xylella fastidiosa. HortScience. 2009;44(7):1928-31.

Lewis AC. Annual report of the state entomologist. Bulletin 58. 1919. Atlanta, GA. May 1920

Lewis AC. Annual report of the state entomologist. Bulletin 60. 1921. Atlanta, GA. May 1921

Macallister C, Eason N, Fuder J, Williams J, Scaduto J, Patrick S, et al. End-point detection of Pierce's disease in wine grapes using rapid test kits. Poster. National Association of County Agricultural Agents. 2020.

Mahlein A-K. Plant disease detection by imaging sensors - parallels and specific demands for precision agriculture and plant phenotyping. Plant Dis. 2016;100(2):241-51.

Mauricio FN, Soratto TAT, Diogo JA, Boscariol-Camrgo RL, De Souza AA, Coletta-Filho HD, et al. Analysis of defense-related gene expression in citrus hybrids infected by Xylella fastidiosa. Phytopathology. 2019;109:301-6.

Minsavage GV, Thompson CM, Hopkins DL, Leite RM, Stall RE. Development of a polymerase chain reaction protocol for detection of Xylella fastidiosa in plant tissue. Phytopathology. 1994;84:456-61.

Mizell RF, French WJ. Leafhopper vectors of phony peach disease: feeding site preference and survival on infected and uninfected peach, and seasonal response to selected host plants. J Entomol Sci. 1987;22(1):11-22.

Mizell RF, Andersen PC, Tipping C, Brodbeck B. Xylella fastidiosa diseases and their leafhopper vectors. [Internet]. University of Florida, IFAS Extension. 2008. https://edis.ifas.ufl.edu/pdffiles/IN/IN17400.pdf Accessed 02 Apr 2021.

Moll JN, Martin MM. Comparison of the organism causing greening disease with several plant pathogenic gram-negative bacteria, rickettsia-like organisms and mycoplasma-like organisms. Colloq Inst Nat Sante Rech Med. 1974:33:89-96.

Mollenhauer HH, Hopkins DL. Ultrastructural study of Pierce's Disease bacterium in grape xylem tissue. J Bacteriol. 1974;199:612-8.

Nauen R, Denholm I. Resistance of insects pests to neonicotinoid insecticides: current status and future prospects. Arch Insect Biochem Physiol. 2005;58:200-15.

Neal DC. Phony peaches: a disease occurring in middle Georgia. Phytopathology. 1920;10:106-9.
Newman KL, Almeida RP, Purcell AH, Lindow SE. Cell-to-cell signalling controls Xylella fastidiosa interactions with both insects. Proc Natl Acad Sci. 2004:101:1737-42.

Norton JD, Abrahams BR, Boyhan BE, Huang H. Evaluation of Xylella fastidiosa in Prunus spp. Abstract. $91^{\text {st }}$ Annual Meeting of the American Society for Horticultural Science. Oregon State University, Corvalis. 7-10 August 1994

Nunes LR, Rosato YB, Muto NH, Yanai GM, Silva VS, Leite DB, et al. Microarray analyses of Xylella fastidiosa provide evidence of coordinated transcription control of laterally transferred elements. Genome Res. 2003;13:570-8.

Nunney L, Yuan X, Bromley R, Hartung J, Montero-Astúa M, Moreira L, et al. Population genomic analysis of a bacterial plant pathogen: novel insight into the origin of Pierce's disease of grapevine in the U.S. Public Libr Sci One. 2010;5:e15488.

Nunney L, Vickerman DB, Bromley RE, Russell SA, Hartman JR, Morano LD, et al. Recent evolutionary radiation and host plant specialization in Xylella fastidiosa subspecies native to the United States. Appl Environ Microbiol. 2013;79(7):2189-200.

Nunney L, Schuenzel EL, Scally M, Bromley RE, Stouthamer R. Large-scale intersubspecific recombination in the plant pathogenic bacterium Xylella fastidiosa is associated with the host shift to mulberry. Appl Environ Microbiol. 2014;80:3025-33.

Nyland G, Goheen AC, Lowe SK, Kirkpatrick HC. The ultrastructure of a rickettsialike organism from a peach tree affected with phony disease. Phytopathology. 1973;63:1275-8.

Ogawa JM, Zehr El, Bird GW, Ritchie DF, Uriu K, Uyemoto JK. Compendium of Stone Fruit Diseases. St. Paul, MN: APS Press; 1995.

Okie WT. The Georgia Peach: Culture, Agriculture, and Environment in the American South. New York: Cambridge University Press; 2016.

Okie WR, Pusey PL. USDA Peach Breeding in Georgia: Current Status and Breeding for Resistance to Botryosphaeria. Int Soc Horticult Sci. 1996:374:151-8

Olmo D, Nieto A, Adrover F, Urbano A, Beidas O, Juan A, et al. First detection of Xylella fastidiosa infecting Cherry (Prunus avium) and Polygala myrtifolia plants, in Mallorca Island. Spain: Plant Disease Notes; 2017.

Overall LM, Rebek EJ. Insect vectors and current management strategies for diseases caused by Xylella fastidiosa in southern United States. J Integr Pest Manag. 2017;8(1):1-12.

Peach BPM, In, . Georgia Plant Disease Loss Estimates. Editor. Little EL Annual Publication. 2018;2020:102-11.

Pierce NB. The California vine disease: A preliminary report of investigations. U.S. Department of Agriculture. Division of Vegetable Pathology. Bulletin No. 2. Government Printing Office. 1892.

Purcell, A.H. 1987. Xylem-Inhibiting Bacteria. In: Harris KF, ed. Advances in Disease Vector Research. New York: Springer; 1987. p. 242-266.

Raju BC, Wells JM, Nyland G, Brlansky RH, Lowe SK. Plum leaf scald: Isolation, culture, and pathogenicity of the causal agent. Phytopathology. 1982:72:1460-6.

Randall JJ, French J, Yao S, Hanson SF, Goldberg NP. First report of Xylella fastidiosa in peach in New Mexico. Plant Disease. 2011;95:7.

Rapicavoli J, Ingel B, Blanco-Ulate B, Cantu D, Roper C. Xylella fastidiosa: an examination of a re-emerging plant pathogen. Mol Plant Pathol. 2018;19(4):786-800

Rashed A, Kwan J, Baraff B, Ling D, Daugherty M, Killiny N, et al. Relative susceptibility of Vitis vinifera cultivars to vector-borne Xylella fastidiosa through time. Public Libr Sci One. 2013;8(2):1-8.

Ren Z, Lu J. Muscadine rootstock increased the resistance of Florida hybrid bunch grape cv. 'Blanc du Bois' to Pierce's disease and anthracnose disease. Proc Florida State Horticult Soc. 2002;115: 108-110.

Roberto SR, Farias PRS, Filho AB. Geostatistical analysis of spatial dynamics of citrus variegated chlorosis. Fitopatol Bras. 2002;27:599-604.

Rodrigues JLM, Silva-Stenico ME, Gomes JE, Lopes JRS, Tsai SM. Detection and diversity assessment of Xylella fastidiosa in field-collected plant and insect samples by using 16rRNA and gyrB sequences. Appl Environ Microbiol. 2003;69(7):4249-55.

Sanderlin RS. Susceptibility of some common pecan rootstocks to infection by Xylella fastidiosa. HortScience. 2015;50(8):1183-6.

Sanderlin RS, Heyderich-Alger KI. Effects of pecan bacterial leaf scorch on growth and yield components of cultivar Cape Fear. Plant Dis. 2003:87:259-62. 
Sanderlin RS, Melanson RA. Reduction of Xylella fastidiosa transmission through pecan scion wood by hot-water treatment. Plant Dis. 2008:92:1124-6.

Santiago MB, da Silva MT, Massuco JE, Silva LO, Lucarini R, da Silva DF, et al. In vitro evaluation of essential oils for potential antibacterial effects against Xylella fastidiosa. J Phytopathol. 2018;166(11-12):790-8.

Saponari M, Giampetruzzi A, Loconsole G, Boscia D, Saldarelli P. Xylella fastidiosa in olive in Apulia: Where we stand. Phytopathology. 2019;109(2):175-86.

Savage EF. History of the Georgia Peach Industry. Unpublished manuscript, University of Georgia, Department of Horticulture, Griffin. 1983.

Schaad NW, Postnikova E, Lacy G, Fatmi M, Chang C-J. Xylella fastidiosa subspecies: $X$. fastidiosa subsp. piercei, subsp. nov., X. fastidiosa subspmultiplex subsp. nov., and $X$. fastidiosa subsp pauca subsp. nov. Syst Appl Microbiol. 2004;27:290-300.

Scherm H, Brannen PM, Taylor KC. Georgia's Peach Industry in a Historical Context. J Tree Fruit Prod. 2004;3(2):1-9. https://doi.org/10.1300/J072v 03n02_01.

Schneider K, van der Werf W, Cendoya M, Mourits M, Navas-Cortés JA, Vicent A, et al. Impact of Xylella fastidiosa subspecies pauca in European olives. Proc Natl Acad Sci USA. 2020;117(17):9250-9.

Sicard A, Zeilinger AR, Vanhove M, Schartel TE, Beal DJ, Daugherty MP, Almeida RPP, et al. Xylella fastidiosa: Insights in an Emerging Plant Pathogen. Annu Rev Phytopathol. 2018;2018(56):181-202.

Silva MS, De Souza AA, Takita MA, Labate CA, Machado MA. Analysis of biofilm proteome of Xylella fastidiosa. Proteome Science. 2011;9:58.

Sisterson MS, Chen J, Viveros MA, Civerolo EL, Ledbetter C, Groves RL. Effects of almond leaf scorch disease on almond yield: Implications for management. Plant Dis. 2008;92:409-14.

Smith RE. Phony peach. Diseases of Fruits and Nuts. Circular 120. University of California, Berkeley, CA. 1941.

Stevenson JF, Matthews MA, Greve LC, Labavitch JM, Rost TL. Grapevine susceptibility to Pierce's Disease II: Progression of anatomical symptoms. Am J Enol Vitic. 2004;55:238-45.

Su CC, Chang CJ, Chang CM, Shih HT, Tzeng KC, Jan FJ, et al. Pierce's disease of grapevines in Taiwan: Isolation, cultivation, and pathogenicity of Xylella fastidiosa. J Phytopathol. 2013;161:389-96.

Triapitsyn SV, Phillips PA. First record of Gonatocerus triaguttatus (Hymenoptera: Mymaridae) froms eggs of Homalodisca coagulata (Homoptera: Cicadellidae) with notes on the distribution of the host Florida. Entomologist. 2000;83(2):200-3.

Triapitsyn SV, Hoddle MS, Morgan DJW. A new distribution and host record for Gonatocerus triguttatus in Florida, with notes on Acmopolynema sema (Hymenoptera: Mymaridae). Florida Entomologist. 2002;85:654-5.

Tubajika KM, Civerolo EL, Cioperlik MA, Luvisi DA, Hashim JM. Analysis of the spatial patterns of Pierce's disease incidence in the lower San Joaquin Valley in California. Phytopathology. 2004;94:1136-44.

Turner WF. Insect vectors of phony peach disease. Science. 1949;109:87-8.

Turner WF, Pollard HN. Insect transmission of phony peach disease. United States Department of Agriculture Technical Bulletin 1193. 1959a.

Turner WF, Pollard HN. Life histories and behavior of five insect vectors of phony peach disease. United States Department of Agriculture Technical Bulletin 1188. 1959b.
United States Department of Agriculture - Agriculture Research Service. 1962. Controlling Phony Disease of Peaches. Leaflet No. 515.

United States Department of Agriculture, National Agricultural Statistics Service. Noncitrus fruits and nuts 2019 summary. 2020.

Vanhove M, Retchless AC, Sicard A, Rieux A, Coletta-Filho HD, De La Fuente $L$, et al. Genomic diversity and recombination among Xylella fastidiosa subspecies. Appl Environ Microbiol. 2019;85(13):1-17.

Varani AM, Monteiro-Vitorello CB, de Almeida LGP, Souza RC, Cunhal OL, Lima WC, et al. Xylella fastidiosa comparative genomic database is an information resource to explore the annotation, genomic features, and biology different strains. Genet Mol Biol. 2012;35(1):149-52.

Waliullah S, Hudson O, Oliver JE, Brannen PM, Ji P, Ali ME. Comparative analysis of different molecular and serological methods for detection of Xylella fastidiosa in blueberry. Public Libr Sci One. 2019;14(9):e0221903.

Weaver DJ, Raju BC, Wells JM, Lowe SK. Occurrence in johnsongrass of rickettsia-like bacteria related to the phony peach disease organism. Plant Dis. 1980;64:485-7.

Wells JM, Weaver DJ, Raju BC. Distribution of rickettsia-like bacteria in peach, and their occurrence in plum, cherry, and some perennial weeds. Phytopathology. 1980;70:817-20.

Wells JM, Raju BC, Thompson JM, Lowe SK. Etiology of phony peach and plum leaf scald diseases. Phytopathology. 1981a;71:1156-61.

Wells JM, Raju BC, Nyland G, Lowe SK. Medium for isolation and growth of bacteria associated with plum leaf scald and phony peach disease. Appl Environ Microbiol. 1981b;42(2):357-63.

Wells JM, Raju BC, Hung H-Y, Weisburg WG, Mandelco PL, Brenner DJ. Xylella fastidiosa new-genus new-species Gram-negative xylem-limited fastidious plant bacteria related to Xanthomonas spp. Int J Syst Evol Microbiol. 1987;37(2):136-43.

Welsh, MF. Virus Diseases of Stone Fruit. Handbook No. 437 "Control of Stone Fruit Virus Diseases"1976; p. 10-15.

West JS, Bravo C, Oberti R, Moshou D, Ramon H, McCartney HA. Detection of fungal disease optically and pathogen inoculum by air sampling. In: Oerke EC, Gerhards R, Menz G, Sikora RA, editors. Precision Crop - Protection -The Challenge and Use of Heterogeneity. Dordrecht: Springer; 2010.

Xue J, Su B. Significant remote sensing vegetation indices: a review of developments and applications. J Sens. 2017

Yuan X, Morano L, Bromley R, Spring-Pearson S, Stouthamer R, Nunney L. Multilocus sequence typing of Xylella fastidiosa causing Pierce's disease and oleander leaf scorch in the United States. Phytopathology. 2010:100:601-11.

Zarco-Tejada PJ, Camino C, Beck PSA, Calderon R, Hornero A, Hernández-Clemente $\mathrm{R}$, et al. Previsual symptoms of Xylella fastidiosa infection revealed in spectral plant-trait alterations. Nat Plants. 2018;4:432-9.

\section{Publisher's Note}

Springer Nature remains neutral with regard to jurisdictional claims in published maps and institutional affiliations.

\footnotetext{
Ready to submit your research? Choose BMC and benefit from:

- fast, convenient online submission

- thorough peer review by experienced researchers in your field

- rapid publication on acceptance

- support for research data, including large and complex data types

- gold Open Access which fosters wider collaboration and increased citations

- maximum visibility for your research: over 100M website views per year
}

At BMC, research is always in progress.

Learn more biomedcentral.com/submissions 